\title{
Mechanisms of Tolerance Induction by Dendritic Cells In Vivo
}

\author{
Hitoshi Hasegawa* and Takuya Matsumoto \\ Department of Hematology, Clinical Immunology and Infectious Diseases, Ehime University Graduate School of Medicine, \\ Toon, Japan
}

Dendritic cells (DCs) are a heterogeneous population playing a pivotal role in immune responses and tolerance. DCs promote immune tolerance by participating in the negative selection of autoreactive T cells in the thymus. Furthermore, to eliminate autoreactive T cells that have escaped thymic deletion, DCs also induce immune tolerance in the periphery through various mechanisms. Breakdown of these functions leads to autoimmune diseases. Moreover, DCs play a critical role in maintenance of homeostasis in body organs, especially the skin and intestine. In this review, we focus on recent developments in our understanding of the mechanisms of tolerance induction by DCs in the body.

OPEN ACCESS

Edited by:

John Isaacs,

Newcastle University,

United Kingdom

Reviewed by:

Hans Acha-Orbea,

University of Lausanne,

Switzerland

Raymond John Steptoe, The University of Queensland,

Australia

*Correspondence:

Hitoshi Hasegawa

hitoshih@m.ehime-u.ac.jp

Specialty section: This article was submitted to Immunological Tolerance and Regulation, a section of the journal

Frontiers in Immunology

Received: 08 October 2017 Accepted: 07 February 2018 Published: 26 February 2018

Citation:

Hasegawa $\mathrm{H}$ and Matsumoto $T$ (2018) Mechanisms of Tolerance Induction by Dendritic Cells In Vivo.

Front. Immunol. 9:350. doi: 10.3389/fimmu.2018.00350
Keywords: dendritic cells, immune tolerance, regulatory T cells, development, thymus, skin, intestine

\section{INTRODUCTION}

Dendritic cells (DCs) represent a heterogeneous population derived from distinct hematopoietic lineages of bone marrow origin, being characterized by specific homing patterns and specialized immune functions (1-4). DCs play a pivotal role in immune responses and tolerance. Efficient priming of $\mathrm{T}$ cells by DCs leading to immune responses requires additional signals from the pro-inflammatory environment that can be sensed by DCs through specific pattern recognition receptors including toll-like receptors (TLRs) (mature DCs; mDCs). In contrast, lack of T cell priming in the absence of pro-inflammatory stimuli initially led to the characterization of DCs as potentially tolerogenic immature bystanders under steady-state conditions (immature DCs; iDCs). Semi-mDCs induced by apoptotic cells, by a special cytokine environment such as IL-10 and TGF$\beta$, or by pharmacological agents also show tolerogenic properties (5-7). Tolerogenic DCs (tolDCs) in the body play an essential role in central and peripheral tolerance, resulting in resolution of ongoing immune responses and prevention of autoimmunity. DCs promote immune tolerance through negative selection of autoreactive $\mathrm{T}$ cells and generation of regulatory $\mathrm{T}$ cells (Tregs) in the thymus during acquisition of central tolerance. They also limit the differentiation of effector $\mathrm{T}$ cells and promote that of Tregs in the periphery through various mechanisms. Breakdown of these functions leads to autoimmune diseases. The skin and intestine act as large barrier organs to the external environment, being exposed to a wide range of environmental antigens such as foods, commensal bacteria, and pathogens. In both organs, DCs fulfill a crucial role in the balance of immune responses, leading to homeostasis and prevention of unnecessary inflammation (8). Accordingly, it is important to analyze the role of DCs in the mechanism of immune tolerance. This review presents an overview of our current understanding of the mechanisms of tolerance induction by DCs in the body.

\section{ORIGIN, DIFFERENTIATION, AND SUBSETS}

Dendritic cells originate from $\mathrm{CD} 34^{+}$hematopoietic progenitor cells in the bone marrow, which then differentiate further via common macrophage/DC progenitors into the monocyte/ 
macrophage lineage or common DC progenitors (CDP) (Figure 1A) (9). CDPs give rise to both plasmacytoid DCs (pDCs) and pre-conventional DC (cDC) progenitors. Fmslike tyrosine kinase 3 ligand (FLT3L) and its receptor, FLT3, have an instructive role in the commitment of hematopoietic progenitors to the DC-restricted lineage and their subsequent development $(10,11)$. FLT3L is sufficient to drive DC differentiation from mouse and human precursors, since expression of FLT3 is restricted to the DC lineage (11). Before they migrate into the bloodstream, pDCs complete their last step of maturation in the bone marrow before they migrate into the blood stream. Pre-cDC progenitors then migrate through the vascular system to their final locations in tissues or lymphoid organs, before completing their differentiation into iDCs comprising two distinct $\mathrm{cDC}$ subsets, CD $8 \alpha^{+} / \mathrm{CD} 103^{+} \mathrm{DCs}$ [conventional DCs 1 (cDC1s)] and CD $11 b^{+}$DCs [conventional DCs 2 (cDC2s)] (3). On the other hand, monocyte-derived DCs (moDCs) can differentiate from CD $14^{+}$monocytes under the influence of a combination of stimuli, including GM-CSF, TNF- $\alpha$, and IL-4, during tissue inflammation (12, 13). DCs are more numerous in lymphoid organs and epithelia and can express various molecular markers depending on their location. Therefore, $\mathrm{cDC} 1 \mathrm{~s}, \mathrm{cDC} 2 \mathrm{~s}$, and $\mathrm{pDCs}$ are present in different tissues. Figure 1B shows the $\mathrm{cDC}$ cluster to which each cell type belongs. In this context, it is necessary to consider the phenotype and specific location of DCs when addressing their function in particular tissues (9).

In mice, lymphoid organ-resident $\mathrm{CD} 8 \alpha^{+} \mathrm{DCs}$ and migratory tissue-resident $\mathrm{CD} 03^{+}$DCs have a common origin (9). Their development is dependent on FLT3L, inhibitor of DNA binding protein 2, the transcription factor interferon regulatory factor 8 (IRF8), and the basic leucine zipper transcription factor ATFlike 3 (BATF3) (9). Functional and phenotypic comparison has shown that the human counterpart of murine $\mathrm{CD} 8 \alpha^{+} / \mathrm{CD} 103^{+}$
DCs is CD141 (BDCA-3)-positive DCs (14). CD8 $\alpha^{+} / \mathrm{CD} 103^{+}$ DCs share common receptors such as chemokine receptor XCR1 and lectin receptor CLEC9A (15-17). CD8 $\alpha^{+} / \mathrm{CD} 103^{+}$ DCs are responsible for efficient cross-presentation of antigen and stimulation of $\mathrm{CD}^{+} \mathrm{T}$ cell immunity through secretion of IL-12, thus promoting Th1 differentiation $(18,19)$. In contrast, in the non-inflamed intestine, $\mathrm{CD}_{103}{ }^{+} \mathrm{DCs}$ in the lamina propria express high levels of TGF- $\beta$ and retinaldehyde dehydrogenase 2 (RALDH2), leading to induction of Tregs (20). Therefore, $\mathrm{CD} 8 \alpha^{+} / \mathrm{CD} 103^{+} \mathrm{DCs}$ induce either mucosal tolerance or crosspresentation-dependent $\mathrm{CD}^{+} \mathrm{T}$ cell immunity on the basis of the local microenvironment.

In mice, $\mathrm{CD} 11 \mathrm{~b}^{+} \mathrm{DCs}$ are present in all major lymphoid and non-lymphoid organs. Development of CD11b ${ }^{+}$DCs depends on various transcription factors including neurogenic locus notch homolog protein 2, V-Rel avian reticuloendotheliosis viral oncogene homolog B, and IRF4 (9). The human counterpart of murine CD11b ${ }^{+}$DCs is CD1c (BDCA-1)-positive DCs (21). $\mathrm{CD}_{11} \mathrm{~b}^{+} \mathrm{DCs}$ in the spleen express $\mathrm{CD} 4^{+}$and can be subdivided according to their expression of the endothelial cell-selective adhesion molecule (22). Splenic CD $11 b^{+}$DCs show higher expression of MHC class II than $\mathrm{CD} 8 \alpha^{+}$DCs and can present antigen more effectively to $\mathrm{CD} 4^{+} \mathrm{T}$ cells in both the steady state and during inflammation (23). In contrast, CD11 $b^{+}$DCs in the skin and $\mathrm{CD} 11 \mathrm{~b}^{+} \mathrm{CD} 103^{+} \mathrm{DCs}$ in the lamina propria are reported to induce Treg differentiation through retinoic acid (RA) metabolism $(20,24,25)$. Both CD $8 \alpha^{+} / \mathrm{CD} 103^{+} \mathrm{DCs}$ and CD $11 \mathrm{~b}^{+}$ DCs induce tolerance or $\mathrm{CD}^{+}{ }^{+} \mathrm{T}$ cell proliferation according to the local microenvironment.

Murine pDCs are defined as $\mathrm{CD} 11 \mathrm{c}^{+}, \mathrm{MHC}^{-\mathrm{II}^{+}}, \mathrm{B} 220^{+} /$ $\mathrm{CD}_{45 \mathrm{R}^{+}, \mathrm{BST}^{+} \text {, and SiglecH }}{ }^{+}$cells and depend on the transcription factor E2-2 for their development (26). pDCs express high levels of TLR7 and 9, which when ligated by viral products stimulate secretion of a large amount of type I IFN. pDCs can
A

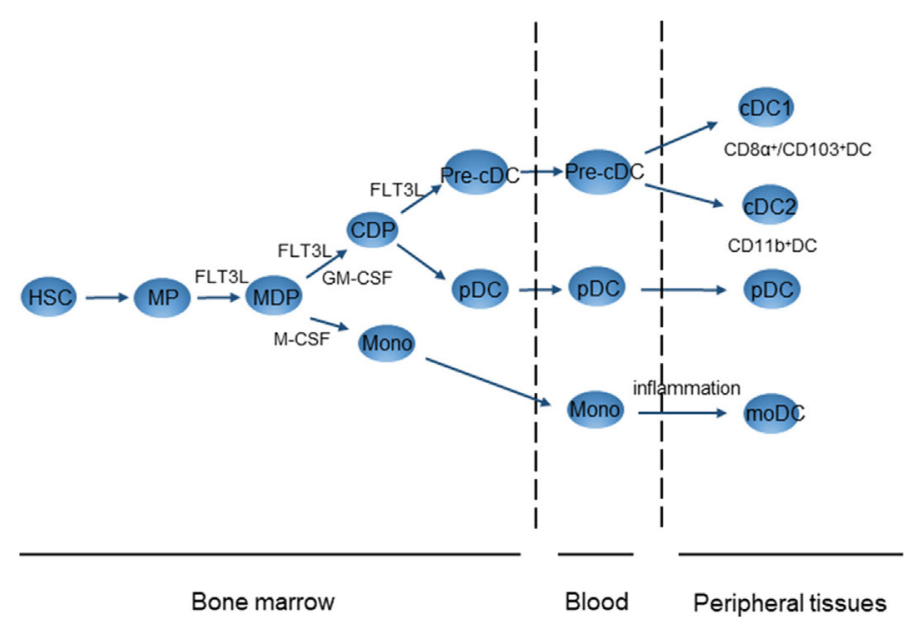

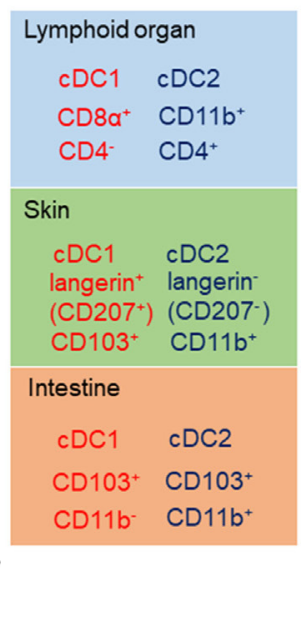

FIGURE 1 | DC development (A) and location and phenotypes of mouse conventional DCs 1 (cDC1s) and conventional DCs 2 (cDC2s) (B). (A) DC, dendritic cells; HSC, hematopoietic stem cells; MP, myeloid procursor; MDP, macrophage/DC progenitor; CDP, common DC progenitor; cDC, conventional DC; pDC, plasmacytoid DC; moDC, monocyte-derived DC. (B) Location and phenotypes of mouse CDC1s (red) and cDC2s (blue). 
upregulate the expression of MHC class II, allowing the induction of $\mathrm{T}$ cell proliferation. On the other hand, murine $\mathrm{pDCs}$ induce differentiation of T cells into regulatory type $1 \mathrm{~T}(\mathrm{Tr} 1)$ cells (27). Naïve T cell stimulation using CpG oligonucleotidestimulated human $\mathrm{pDC}$ has been reported to give rise to Tregs with suppressive properties (28). Phenotypic markers of mouse and human DC subsets are summarized in Table $\mathbf{1 .}$

\section{TOLERANCE INDUCTION IN THE THYMUS AND PERIPHERY}

\section{Central Tolerance}

Dendritic cells together with medullary thymic epithelial cells (mTECs) have a critical role in inducing central tolerance in the thymus by elimination of self-antigen-reactive thymocytes and generation of Tregs $(2,29)$. This is supported by the fact that mice lacking DCs show marked accumulation of $\mathrm{CD}^{+}$ thymocytes without negative selection, leading to fatal autoimmunity (30). Three thymic DC subsets contribute to central tolerance: resident $\mathrm{DCs}\left(\mathrm{CD} 8 \alpha^{+} \mathrm{SIRP} \alpha^{-}\right)$, migratory $\mathrm{DCs}$ $\left(\mathrm{CD} 8 \alpha^{-} \mathrm{CD}_{11} \mathrm{~b}^{+} \mathrm{SIRP} \alpha^{+}\right)$, and pDCs (CD11 $\left.c^{\text {int }} \mathrm{CD} 45 \mathrm{RA}^{\mathrm{int}}\right)$. Resident DCs that develop from thymic lymphoid precursors are the most abundant subset $(>50 \%)$ and are localized mainly in the medulla $(31,32)$. They contribute to the elimination of autoreactive thymocytes by presenting broadly expressed selfantigens and by cross-presenting both blood-derived antigens and tissue-specific antigens from mTECs $(33,34)$. On the other hand, migratory DCs and pDCs develop in the periphery and migrate to the corticomedullary perivascular space, which is freely permeable to circulating antigens via CCR $2 / \alpha 4$ integrin and CCR9/ 4 integrin, respectively $(35,36)$. Through this strategic location, migratory DCs and pDCs effectively capture and present blood-derived antigens. All of the DC subsets contribute to immune tolerance by presenting self-antigens and inducing negative selection of thymocytes with high affinity for self-antigens. Then, resident DCs provide immature T cells with a distinct self-antigenic repertoire, while migratory DCs and pDCs specialize in the presentation of peripheral antigens.

Thymic DCs are also important for the development of Tregs. Resident and migratory DCs are able to induce Tregs from thymocytes in vitro through different mechanisms $(37,38)$. Resident DCs promote Treg survival via their expression of CD70, while CD70-deficient migratory DCs effectively induce Tregs through an undefined pathway (38). Thymic stromal lymphopoietin (TSLP) expressed by Hassall's corpuscles in the thymus medulla induces the tolerogenic phenotype on bone marrow-derived DCs, rendering them capable of converting naïve $\mathrm{T}$ cells into functional Tregs in vitro $(39,40)$. However, TSLP receptor-deficient mice have a normal number of Tregs in the thymus, suggesting that TSLP signaling is not essential for Treg development $(29,41)$. Thymic pDCs can also induce Tregs $(42,43)$ that are more efficient producers of IL-10 than those induced by other thymic DCs. These findings show that all of the DC subsets in the thymus are essential for the maintenance of central tolerance.

Recently, it has been examined how mTECs and CD $8 \alpha^{+}-$ resident DCs contribute to thymic tolerance using mice depleted of mTECs and/or resident DCs (44). Although mice depleted of resident DCs were normal and those depleted of mTECs developed liver inflammation, depletion of both resident DCs and mTECs resulted in multiorgan autoimmunity. Depletion of mTECs significantly reduced the production of thymic Tregs, but there was no additional effect on thymic Tregs when both mTECs and resident DCs were absent. Both $\mathrm{CD} 4^{+}$and $\mathrm{CD} 8^{+} \mathrm{T}$ cells in the thymus were increased in mice depleted of both mTECs and resident DCs. These results suggest that mTECs and resident DCs act to prevent autoimmunity through thymic T cell depletion in a cooperative manner, whereas mTECs have a non-redundant role in the production of thymic Tregs. Thus, mTECs and resident DCs have a unique role in tolerance induction that cannot be compensated for by remaining migratory DCs and $\mathrm{pDCs}$.

The lymphotoxin $\beta$ receptor (LT $\beta R$ ), a member of the TNF receptor superfamily, is a key regulator of thymic microenvironments and intrathymic tolerance, and its expression is detectable in multiple mTEC subsets $(45,46)$. The relationship between LT $\beta$ R and coordination of mTECs and DCs for negative selection and Treg development has been recently investigated using LT $\beta$ R-deficient mice (47). In LT $\beta$ R-deficient mice, the thymic DC pool size was decreased due to reduced numbers of both pDCs and thymic cDCs, especially migratory DCs. In addition, LT $\beta$ R-deficient mice showed a greater reduction in the numbers of $\mathrm{CD} 4^{+} \mathrm{CD} 8^{-}$thymocytes and caspase $-3^{+} \mathrm{CD} 5^{+} \mathrm{CD} 69^{+}$ thymocytes, representing cells undergoing negative selection, although they showed no change in Treg generation relative to control mice. These findings indicate that LT $\beta \mathrm{R}$ controls thymic tolerance by regulating the frequency and makeup of intrathymic DCs required for effective thymocyte negative selection rather than Treg generation.

\section{Peripheral Tolerance}

Although thymic selection efficiently removes most self-antigenreactive $\mathrm{T}$ cells, some remain and migrate into the periphery. Therefore, peripheral tolerance is crucial for maintenance of immune homeostasis throughout life. Tregs of thymic origin and peripheral DCs are crucial in inducing tolerance to antigens under steady-state conditions (Figure 2) (1, 48). The tolDC population consists of iDCs (naïve DCs) and alternatively activated DCs (semi-mature) that exhibit resistance to maturation in the presence of an inducing signal $(5,48)$. iDCs derived from bone marrow constitutively migrate throughout the periphery and lymphatic systems and become distributed in peripheral tissues. iDCs are poorly immunogenic as they show low surface expression of costimulatory molecules and have only modest levels of MHC class II $(1,48)$. A major functional characteristic of iDCs is their capacity for endocytosis and phagocytosis, including both foreign antigens and apoptotic cells, which occurs continuously in the steady state. The maintenance of DCs in an immature state, due to the absence of maturation stimuli, is associated with tolerance through induction of $\mathrm{T}$ cell deletion, anergy, and polarization toward a regulatory phenotype (4). Antigen-loaded iDCs in draining secondary lymphoid organs are more effective at inducing antigen-specific Treg populations than lymphoid-resident DCs in vivo (49). This supports a role for migratory iDCs in promoting peripheral tolerance under 
TABLE 1 | Phenotypic markers of mouse and human dendritic cell (DC) subsets.

\begin{tabular}{|c|c|c|c|}
\hline DC subset & $\begin{array}{l}\text { Conventional } \\
\text { DCs } 1\end{array}$ & $\begin{array}{l}\text { Conventional } \\
\text { DCs } 2\end{array}$ & $\begin{array}{l}\text { Plasmacytoid } \\
\text { DC }\end{array}$ \\
\hline Mouse & CD8 $\alpha^{+} / \mathrm{CD} 103^{+} \mathrm{DCs}$ & CD11b+ DCs & \\
\hline Human & CD141+ DCs & $\mathrm{CD}_{1 \mathrm{c}^{+}} \mathrm{DCs}$ & \\
\hline $\begin{array}{l}\text { Markers } \\
\text { Common (mouse } \\
\text { and human) }\end{array}$ & $\begin{array}{l}\mathrm{BTLA}^{+} \\
\mathrm{MHCl}^{+} \\
\mathrm{CD}^{+} 5^{+} \\
\mathrm{CD}^{+} 4^{-} \\
\mathrm{CD}_{11 \mathrm{C}^{+}} \\
\mathrm{CCR}^{+} \\
\mathrm{FLT3}^{+} \\
\mathrm{CD}^{+} 6^{+} \\
\mathrm{XCR}^{+} \\
\mathrm{CLEC9A}^{+} \\
\mathrm{TLR3}^{+}\end{array}$ & $\begin{array}{l}\mathrm{BTLA}^{+} \\
\mathrm{MHCll}^{+} \\
\mathrm{CD} 45^{+} \\
\mathrm{CD} 4^{-} \\
\mathrm{CD}^{-} 1 \mathrm{C}^{+} \\
\mathrm{CCR}^{+} \\
\mathrm{FLT3}^{+} \\
\mathrm{CD}^{+} \\
\mathrm{CX}^{+} \mathrm{CR} 1^{+} \\
\mathrm{CD}_{11 b^{+}} \\
\mathrm{SIRP} \alpha^{+}\end{array}$ & $\begin{array}{l}\mathrm{BTLA}^{+} \\
\mathrm{MHCl}^{+} \\
\mathrm{CD}^{+} 5^{+} \\
\mathrm{CD}^{-} 4^{-} \\
\mathrm{CD}^{-} \mathrm{RA}^{+} \\
\mathrm{CD}^{+} 3^{+} \\
\mathrm{CD}^{+}\end{array}$ \\
\hline Mouse only & $\begin{array}{l}\text { CD8 } \alpha^{+} \\
\text {CD103 } \\
\text { CD205 } \\
\text { Langerin }\end{array}$ & $\mathrm{CD}^{2} 4^{+}$ & $\begin{array}{l}\mathrm{B} 220 / \mathrm{CD}_{4} \mathrm{R}^{+} \\
\mathrm{BST}^{+} \\
\mathrm{Ly}^{+} \mathrm{C}^{+} \\
\text {SiglecH }^{+}\end{array}$ \\
\hline Human only & $\begin{array}{l}\mathrm{CD}^{+} \\
\mathrm{CD}^{+} 41^{+}\end{array}$ & 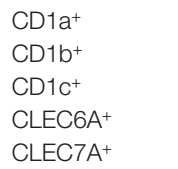 & $\begin{array}{l}\mathrm{CD} 303^{+} \\
\mathrm{CD}^{+} 34^{+}\end{array}$ \\
\hline
\end{tabular}

steady-state conditions. Furthermore, repetitive stimulation of $\mathrm{T}$ cells with iDCs can convert naïe $\mathrm{T}$ cells to Tregs $(50,51)$. Uptake of apoptotic cells polarizes DCs to a tolerogenic state, resulting in the promotion of T cell anergy and death and induction of Tregs via TGF- $\beta 1$ secretion $(52,53)$. These data indicate that apoptotic cells are likely an insufficient stimulus for full DC maturation.

Dendritic cell subsets that differentiate through TLR ligands or in a specific cytokine environment might have involvement in tolerance, rather than in $\mathrm{T}$ cell activation $(1,48)$. This DC type has a semi-mature phenotype with reduced expression of MHC class II and costimulatory molecules in comparison to fully mDCs. Semi-mDCs differentiate in the presence of IL- 6 or by stimulation with TLR ligands at low concentrations $(54,55)$. Stimulation of iDCs with TLR2 or TLR4 ligands at low concentration with the commensal bacterium Bacteroides vulgatus, which colonizes the intestinal tract, leads to secretion of IL-6, but not IL-12 or TNF- $\alpha$ (56). These DCs themselves differentiate into semi-mDCs through an autocrine loop, and exposure of iDCs to IL-6 (paracrine loop) triggers their differentiation to semi-mDCs. Furthermore, tolerogenic semi-mDCs are induced in the presence of IL-10 or TNF- $\alpha$ alone (57-60).

Several studies have demonstrated which DC subtypes contribute to peripheral Treg induction by combining methods of antigen delivery to DCs with diverse genetic mouse models lacking specific DC subtypes (1). Targeting of antigens to $\mathrm{CD} 8 \alpha^{+} / \mathrm{CD} 103^{+} \mathrm{DCs}$ using recombinant chimeric antibodies such as DEC205, CLEC9A, and langerin results in the induction of peripheral Tregs (49, 61-63). Moreover, peripheral Treg induction is impaired through a reduction in the proportion of $\mathrm{CD} 8 \alpha^{+} / \mathrm{CD}_{103}{ }^{+} \mathrm{DCs}$ in BATF3-deficient mice and
IRF8-deficient mice; both are transcription factors that are required for the development of $\mathrm{CD} 8 \alpha^{+} / \mathrm{CD} 103^{+} \mathrm{DCs}(64,65)$. In contrast, Treg induction is restored in mice deficient in IRF4, a transcription factor that governs CD $11 b^{+}$DCs development. These data indicate that $\mathrm{CD} 8 \alpha^{+} / \mathrm{CD} 103^{+} \mathrm{DCs}$ rather than CD $11 b^{+}$DCs contribute to peripheral Treg induction.

Tolerogenic DCs show expression of immunomodulatory molecules and produce immunosuppressive factors such as IL-10, TGF- $\beta$, IL-35, and indoleamine 2,3-dioxygenase (IDO), resulting in T cell anergy and apoptosis and induction of Tregs $(2,48)$. The following section outlines these mechanisms.

\section{MECHANISMS OF IMMUNE TOLERANCE BY DCs}

\section{T Cell Anergy}

Anergy is a hyporesponsive state in which $\mathrm{T}$ cells remain inactive under conditions where immune activation would be undesirable, thus ensuring recognition of self-antigens and maintenance of a steady state (66). Anergy is induced in $\mathrm{T}$ cells that recognize antigen in the absence of costimulatory signals resulting from binding of CD28 on their surface to its ligand, CD80/CD86, on DCs. Consequently, IL-2 production is blocked, and $\mathrm{T}$ cells are unable to proliferate the same antigen $(5,67)$. Anergy can also be induced by coinhibitory signals such as programmed cell death-1 (PD-1) receptor and cytotoxic T lymphocyte antigen 4 (CTLA-4) $(68,69)$. PD-1 binds to PD-1 ligand (PD-L1) and PD-L2 on DCs, whereas CTLA-4 interacts with CD80/CD86 on DCs.

Several studies have shown that tolDCs can induce antigenspecific anergy through various mechanisms (70-73). tolDCs generated with IL-10 induced hyporesponsiveness of tetanus toxin (TT)-specific $\mathrm{CD} 4^{+} \mathrm{T}$ cell clone toward restimulation with TT-pulsed DCs (70). This inhibition of T cell proliferation was due not to release of soluble inhibitor factors from tolDCs but to a cell contact mechanism. Tuettenberg et al. have demonstrated that induction of anergy in $\mathrm{CD} 4^{+} \mathrm{T}$ cells by IL-10-modulated tolDCs was based on cell-to-cell contact through interaction of inducible T-cell costimulatory (ICOS)-ICOS ligand (ICOS-L) (71). Torres-Aguilar et al. showed that tolDCs generated with different combinations of the cytokines IL-10, TGF- $\beta$, and IL- 6 induced anergy of TT-specific CD4 ${ }^{+} \mathrm{T}$ cells through thrombospondin-1 expression and production of prostaglandins and adenosine by tolDCs (72). Recently, Rodriguez et al. have reported that interaction of the dendritic cell-specific intercellular adhesion molecule-3-grabbing non-integrin with pathogens triggers specific signaling events that modulate DC maturation and activity, resulting in induction of T-cell anergy (73).

Induction and maintenance of T-cell anergy depend on activation of ubiquitin ligases of E3 family: Casitas B-lineage lymphoma-b (Cbl-b), Itchy homolog E3 ubiquitin protein ligase (Itch), and gene related to anergy in lymphocytes (GRAIL) (74). These enzymes act mainly through induction of proteolysis of molecules involved in TCR signaling $(66,67)$. T cells from Cbl-b- or Itch-deficient mice were hyperreactive and produced an increased amount of IL-2 (75-78). GRAIL was upregulated 


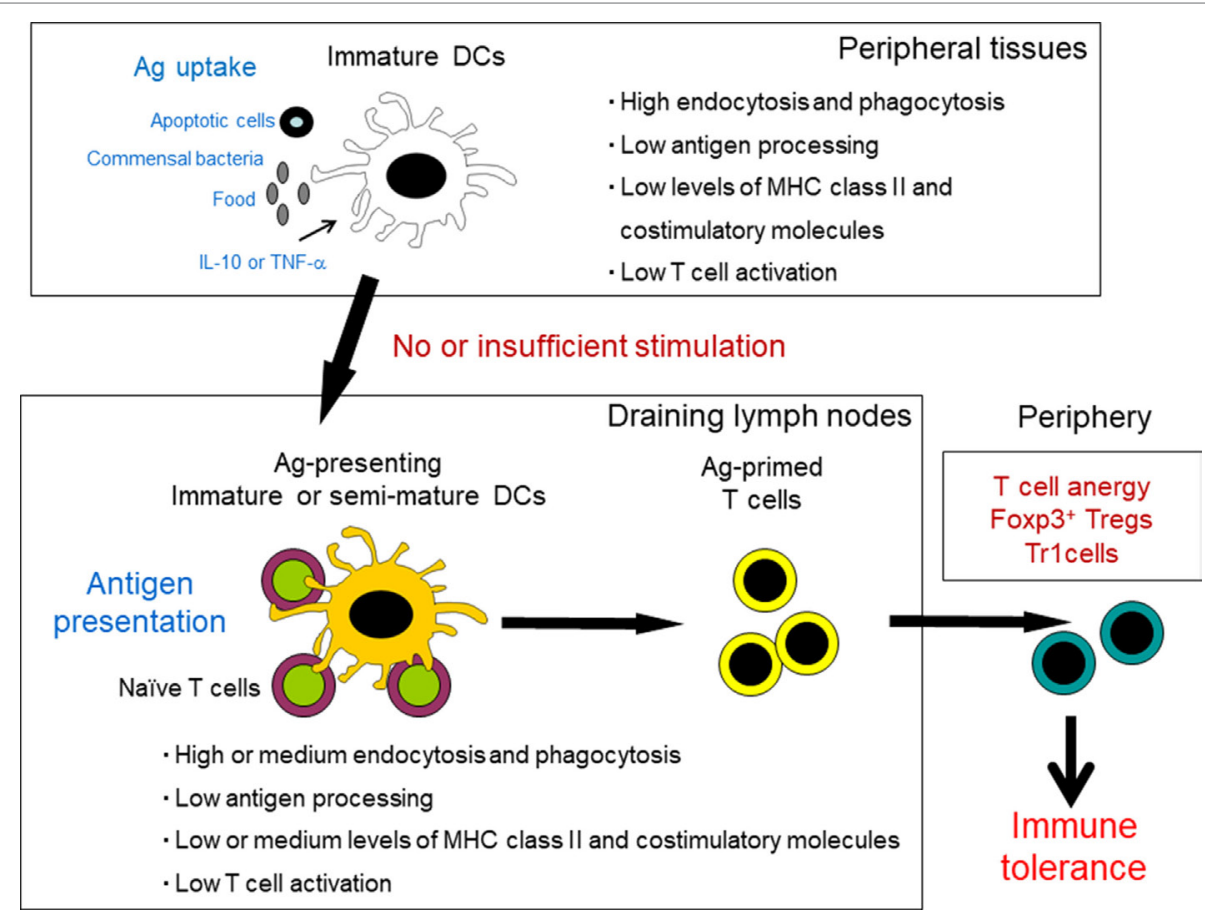

FIGURE 2 | Induction of tolerance by peripheral dendritic cells (DCs) under steady-state conditions. Tissue-resident, immature DCs capture self-antigens from apoptotic cells, commensal bacteria, and food antigens. Under steady-state conditions, these DCs migrate to the draining lymph nodes without sufficient maturation. Antigen-presenting immature or semi-mature DCs provide insufficient stimulatory signals for $T$ cells and therefore drive naïve $T$ cells to anergy and differentiation into regulatory $\mathrm{T}$ cells and regulatory type $1 \mathrm{~T}$ (Tr1) cells.

in anergic $\mathrm{CD} 4^{+} \mathrm{T}$ cells (79). In addition, the expression of these ubiquitin ligases in anergic $\mathrm{T}$ cells is associated with transcriptional factors, early growth response (Egr) type 2 and 3 (80). Blockade of Egr2 and Egr3 is resistant to anergy induction, while the transgenic expression of these factors suppresses TCR signaling $(81,82)$. In addition, anergic T cells could also act as Tregs and IL-10-producing $\operatorname{Tr} 1$ cells (83-86).

\section{Clonal Deletion}

Clonal deletion, which involves the elimination of T cells through apoptosis, is an important process for maintenance of self-tolerance in the periphery (87). Apoptotic pathways can be triggered by extrinsic (receptor-dependent) and intrinsic (mitochondriadependent) stimuli $(88,89)$. Both pathways involve a cascade of caspases whose activation commits cells to a death outcome. The extrinsic apoptosis pathway is initiated by binding of death receptors such as Fas and TNF receptor. Ligation of FasL, TNF, or TNF-related apoptosis-inducing ligand (TRAIL) to death receptors results in activation of caspase 8 and downstream caspases and, ultimately, cell death. tolDCs can also induce naïve and memory $\mathrm{T}$ cell apoptosis through interaction between FasL and Fas (90), TRAIL interaction with TRAIL receptors (91), and tryptophan catabolism due to IDO production $(92,93)$.

Tolerogenic DCs induce extensive $\mathrm{T}$ cell apoptosis in a manner dependent on interaction between DC FasL and Fas expressed by the target lymphocytes. Recently, a new immunosuppressive action of DCs through the Fas signal has been reported (94). Splenic stroma-educated tolDCs expressed a high level of Fas, and Fas ligation was able to promote the inhibition of $\mathrm{CD}^{+} \mathrm{T}$ cell proliferation by tolDCs more significantly. Furthermore, Fas ligation preferentially induced tolDCs to produce IL-10. In addition, activated T cells promoted the secretion of more IL-10 by tolDCs through FasL. This shows that, at least from activated T cells, the Fas signal can promote the immunosuppressive action of Fas-expressing tolDCs, providing a new path for regulation of adaptive immunity by tolDCs. The cellular and molecular mechanisms of Fas-independent apoptosis of T cells induced by DCs have also been investigated by in vitro and in vivo analyses in MRL/lpr mice (95). This has revealed that FAS-independent $\mathrm{T}$ cell apoptosis can be induced by direct interaction between TRAIL receptor 2 on T cells and TRAIL on Fas-deficient DCs in MRL/lpr mice.

Indoleamine 2,3-dioxygenase is a rate-limiting enzyme that catalyzes the degradation of tryptophan into various metabolites, which subsequently inhibit $\mathrm{T}$ cell proliferation by impairing the cell cycle machinery and promoting apoptosis $(48,92,93,96,97)$. IDO is not expressed constitutively in DCs and requires induction by various mediators including IFN- $\gamma$, TGF- $\beta$, and endotoxin (97). In rodents, CD $103^{+}$DCs in mesenteric lymph nodes (MLNs) and intestinal mucosa are known to express IDO. When IDO activity is inhibited, Th1 and Th17 cells are induced in vivo, preventing the development of Tregs that are specific for oral antigens (98). In contrast, tryptophan starvation increases the expression of the inhibitory receptors, 
immunoglobulin-like transcript 3 (ILT3) and ILT4, on DCs, leading to upregulation of Treg function. This phenomenon is associated with the GCN2 kinase-mediated stress response pathway (99).

Galectins, a family of $\beta$-galactoside-binding proteins, are expressed on DCs and also induce apoptosis of T cells (100-103). Especially, galectin 9 preferentially induces apoptosis of activated $\mathrm{CD}^{+} \mathrm{T}$ cells through the calcium-calpain-caspase 1 pathway (101). Galectin 9 is a ligand of T cell immunoglobulin- and mucin domain-containing molecule 3 (Tim-3) expressed in Th1 cells, and the galectin 9-induced cell death in Th1 cells is dependent on Tim-3 (104).

The intrinsic apoptosis pathway can be triggered by various stimuli such as gamma irradiation, pathogens, steroid hormone, and reactive oxygen radicals and by costimulatory blockade with CTLA-4 $(88,89,105,106)$. This pathway is induced by a change in mitochondrial membrane potential provoked by the Bcl-2 family of proteins (89). Cytochrome $c$ is then released by the mitochondria, binds to the apoptotic protease-activating factor 1, and forms an apoptosome that triggers the activation of caspase 9, leading to cell death. $\mathrm{Bcl}-\mathrm{x}_{\mathrm{L}}$ and $\mathrm{Bcl}-2$ impair intrinsic apoptosis by maintaining mitochondrial integrity (88). It has been reported that $\mathrm{Bcl}-\mathrm{x}_{\mathrm{L}}$ transgenic mice were resistant to induction of transplantation tolerance through costimulatory blockade, whereas a Bcl-2/Bcl- $\mathrm{x}_{\mathrm{L}}$ inhibitor (ABT-737), in combination with costimulatory blockade and donor bone marrow cells, induced complete peripheral deletion of alloreactive T cells $(105,107,108)$. On the other hand, the Bcl-2 family protein Bim present on mitochondrial membranes is involved in TCRinduced apoptosis, since deficiency of Bim impairs apoptosis of autoreactive thymocytes and mature T cells $(109,110)$. Taken together, these findings indicate that the intrinsic apoptosis pathway plays a critical role in not only peripheral $\mathrm{T}$-cell homeostasis but also central tolerance.

\section{Induction of Tregs}

Tolerogenic DCs can induce several subtypes of Tregs such as $\mathrm{CD} 4^{+} \mathrm{CD} 25^{+} \mathrm{Foxp}^{+} \mathrm{T}$ cells and $\mathrm{Tr} 1$ cells. This can be achieved through a number of mechanisms, including direct cell-cell contact-dependent signaling via surface molecules, as well as by alteration of Treg fate via secretory proteins (3). DCs are known to mediate Treg generation via several surface molecules, including CD80/CD86 (111, 112), ICOS-L (113), ILT3, and ILT4 (114) and PD-L1 or PD-L2 (115-117). Tolerance can be induced by presentation of MHC class II antigen by DCs without any additional costimulatory signal such as CD80/CD86 and ICOS-L or in combination with a coinhibitory signal such as PD-L1/2 and ILT3/4. Furthermore, ligation of CD80/CD86 by CTLA-4 drives Treg differentiation, whereas insufficient ligation of CD80/CD86 by CD28 leads to tolerance induction. ICOS-L expressed by DCs binds to its receptor on T cells and maintains the homeostasis of Tregs.

Recently, it has been demonstrated that DCs require B- and T-lymphocyte attenuator (BTLA), an immunoglobulin domain superfamily protein, to induce Tregs (64). BTLA is specifically expressed in DEC205 ${ }^{+} \mathrm{CD} 8 \alpha^{+}$DCs. Anti-BTLA antibody, which prevents BTLA binding to its ligand, the herpes virus entry mediator (HVEM), expressed on T cells, dramatically reduces Treg conversion. In addition, in BTLA-deficient mice, Treg induction is also decreased. BTLA mediates the upregulation of CD5 expression in T cells through HVEM engagement-increased phosphorylation of mitogen-activated protein kinase kinase (MEK). MEK increases the expression of the Cd5-positive regulator ETS1 and inhibits the expression of the Cd5-negative regulator TCF-3. CD5 is expressed on all $\mathrm{T}$ cells and is a well-established negative regulator of TCR signaling. CD5 promotes Treg conversion in response to self and tolerizing peripheral antigens by blocking the activation of mechanistic target of rapamycin (118).

Dendritic cells secrete many factors that are known to induce tolerance and Treg generation. IL-10, produced in the surrounding milieu under tolerogenic conditions, can trigger the development of iDCs into semi-mature tolDCs in peripheral tissues. In turn, these tolDCs acquire the ability to generate IL-10 and migrate to neighboring lymphoid organs, where IL-10 produced by DCs regulates the development and proliferation of $\mathrm{CD}^{+}{ }^{+} \mathrm{CD} 25^{+} \mathrm{Foxp}^{+} \mathrm{T}$ cells and $\mathrm{Tr} 1$ cells $(48,117)$. IL- 10 also plays a pivotal role in regulating the expression of immune-inhibitory molecules. IL-10 upregulates the surface expression of ILT3 and ILT4 (114), PD-L1 (119), and CD95L (120) on DCs, leading to regulatory function and apoptosis.

TGF- $\beta$ promotes the conversion of peripheral naïve T cells to Tregs through induction of Foxp3 expression (121). Similarly, several studies have demonstrated that DCs promote extrathymic Treg differentiation in a TGF- $\beta$-dependent manner $(72,122)$. Inhibition of $\mathrm{T}$ cell-specific TGF- $\beta$ signaling via expression of a dominant-negative TGF $\beta$ RII blocks the differentiation of Tregs (62). Coculture of Tregs with DCs results in secretion of IL-10, IL-27, and TGF- $\beta$ by DCs, leading to the differentiation of $\operatorname{Tr} 1$ cells (123). DC-derived IL-27 suppresses the secretion of IL-1 $\beta$ and IL-23, induces the production of IL-10, and blocks Th17 differentiation (124). Through activation of STAT1 and STAT3, DC-derived IL-27 drives the transcription of IL-10 and activates the IL-10 promoter, thus inducing $\operatorname{Tr} 1$ differentiation (125). Moreover, IL-27 induces expression of the immunoregulatory molecule CD39, leading to suppression of T cell responses and autoimmunity (126). Gut-located DCs are a major source of RA, which promotes the generation of Tregs, while simultaneously inhibiting Th17 cells $(127,128)$.

Tolerogenic DCs secreted an anti-inflammatory cytokine, IL-35, and its production was enhanced upon stimulation with IFN- $\gamma$, LPS, or CD40 ligand (129). Conversely, IL-35 induced the conversion of $\mathrm{cDCs}$ to tolDCs (130). In addition to tolDCs, IL-35 is also secreted from Tregs and regulatory B cells (131-134). IL-35 is a member of the IL-12 family, consisting of IL- $12 \alpha$ subunit p35 and IL-27 $\beta$ subunit Epstein-Barr virusinduced gene 3 and contributes to controlling homeostatic proliferation by suppressing $\mathrm{T}$-cell proliferation and function $(131,132,135)$. IL-35 could induce naïve T cells to differentiate into IL-35-producing Foxp3-induced Tregs, which maintain self-tolerance and promote infectious tolerance (131). IL-35 also plays an essential role in the balance between Th17 cells and Tregs through suppression of Th17 differentiation $(132,136)$. Moreover, a recent study has reported that mice vaccinated with 
IL-35-producing DCs showed promotion of tumor growth and amelioration of autoimmune encephalitis (130). Taken together, these findings suggest that IL-35 plays a significant role in the regulation of immune tolerance.

Plasmacytoid DCs induce Treg differentiation in the peripheral lymph nodes (137). Although, in the steady state, pDCs express very low levels of MHC class II and costimulatory molecules, activated pDCs upregulate MHC class II and migrate to the T cell area to induce Treg generation. Type I IFN and IL-10 produced by $\mathrm{pDC}$ contribute to Treg generation. $\mathrm{pDCs}$ can also produce IDO and express PD-L1, and this is correlated with an increase of Treg numbers $(115,138)$.

Regulatory $\mathrm{T}$ cells are also able to affect $\mathrm{DC}$ function. Mutual interaction between DCs and Tregs is required for maintenance of immune tolerance: tolDCs induce Tregs, and conversely Tregs prepare DCs for an immunosuppressive role, thus extending the immunosuppressive function of Tregs. For example, IL-10 and TGF- $\beta$ locally secreted from Tregs are able to suppress the maturation of DCs and render them tolerogenic (139). Another pivotal role of Tregs is their immunosuppressive effect when in contact with DCs. Recently, individual Treg-DC interaction events in lymph nodes have been examined in vivo using imaging techniques (140). Endogenous Tregs exhibited enhanced adhesion to antigen-presenting DCs, thus mediating the activation of conventional $\mathrm{CD} 4^{+} \mathrm{T}$ cells ( $\mathrm{T}$ conv cells) in draining lymph nodes. Subsequent experiments using adoptive transfer of Tregs and MHC class II-deficient DCs have demonstrated that this increased Treg-DC adhesion can be promoted only by exposure to IL-2 without requiring MHC recognition. Importantly, physical contact with polyclonal Tregs significantly reduces the ability of DCs to form stable conjugates with cognate $\mathrm{T}$ conv cells in vivo, resulting in impaired $\mathrm{T}$ cell priming. These results suggest that Tregs of any TCR specificity can suppress DCs in a contact-dependent and MHC class II-independent manner. Moreover, the dynamic cytoskeletal components underlying contact-dependent Treg-mediated DC suppression have been analyzed using imaging (141). This revealed that Tregs, rather than T conv cells, exhibited strong intrinsic adhesiveness to DCs. This adhesion of Tregs caused sequestration of Fascin-1, an actin-bundling protein essential for the formation of immunological synapses and skewed Fascin-1-dependent actin polarization in DCs toward the Treg adhesion zone. This sequestration caused DCs to become lethargic, leading to reduced $\mathrm{T}$ cell priming. Mechanisms of immune tolerance by tolDCs are summarized in Table 2.

\section{INDUCTION OF IMMUNE TOLERANCE BY DCs IN THE SKIN AND INTESTINE}

\section{Skin}

The skin is the largest barrier organ separating the internal milieu from the external environment. It is exposed to not only physical stress but also a huge number of environmental antigens, including chemicals, commensal bacteria, and pathogens. Therefore, the immune system of the skin must detect and discriminate between these diverse antigens and induce appropriate
TABLE 2 | Mechanisms of DC-induced immune tolerance.

T cell anergy

- CD80/86-CTLA-4 interaction

- PD-L1/L2-PD-1 interaction

- ICOS-L-ICOS interaction

- Thrombospondin-1 expression

- Production of prostaglandins and adenosine

- Interaction of DC-SIGN with pathogens

Clonal deletion (apoptosis)

- FasL-Fas interaction

- TRAIL-TRAIL receptor interaction

- Tryptophan catabolism via IDO production

- Galectin 9-Tim-3 interaction

- Intrinsic (mitochondria-dependent) apoptosis pathway

Induction of Tregs

- PD-L1/L2-PD-1 interaction

- ICOS-L-ICOS interaction

- CD80/86-CTLA-4 interaction

- Expression of ILT3 and ILT4

- Production of anti-inflammatory cytokines (IL-10, TGF- $\beta$, IL-27, and IL-35)

- BTLA-HVEM interaction

- Production of RA

- Tryptophan catabolism via IDO production

- IL-10 production by Fas-expressing tolerogenic DCs

- Plasmacytoid DCs function

Other suppressive mechanisms

- Mutual interaction between DCs and Tregs

CTLA-4, cytotoxic T lymphocyte antigen 4; $P D-1$, programmed cell death-1; $P D-L 1$, programmed cell death-1 ligand; ICOS-L, inducible T-cell costimulatory ligand; DCSIGN, dendritic cell-specific intercellular adhesion molecule-3-grabbing non-integrin; TRAIL, TNF-related apoptosis-inducing ligand; IDO, indoleamine 2,3-dioxygenase; Tim-3, T cell immunoglobulin- and mucin domain-containing molecule 3; ILT3, immunoglobulin-like transcript 3; BTLA, B- and T-lymphocyte attenuator; HVEM, herpes virus entry mediator; RA, retinoic acid; Tregs, regulatory T cells; DCs, dendritic cells.

tolerogenic or protective responses (142). The skin consists of two anatomically distinct layers, the epidermis and dermis, which are separated by a basement membrane. Langerhans cells (LCs), expressing the C-type lectin langerin (CD207), represent the sole tissue-resident DC population in the epidermis, while several subsets of DCs are resident in the dermis, including $\mathrm{CD}_{103^{+}}$

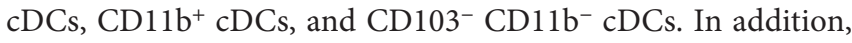
during inflammation, moDCs are recruited to the dermis (8). LCs are very motile, although most abundant in the spinous layer of the epidermis. LCs constantly migrate from the skin to draining lymph nodes even under steady-state conditions. In general, LCs induce effector-type immunity to pathogens and foreign proteins $(143,144)$. On the other hand, recent evidence suggests that LCs might be involved in peripheral tolerance induction. In a murine model of contact hypersensitivity (CHS), it has been demonstrated that the absence of LCs leads to an increase in the number of hapten-specific $\mathrm{CD}^{+}$and $\mathrm{CD} 8^{+} \mathrm{T}$ cells. This has revealed a mechanism of immune regulation in the skin whereby interplay with $\mathrm{CD}^{+} \mathrm{T}$ cells enables LCs to suppress antigen-specific responses through IL-10 production (145). Another CHS study involving experimental depletion and adoptive transfer has demonstrated that LCs confer protection against CHS development through a mechanism involving both anergy and deletion of allergen-specific $\mathrm{CD}^{+} \mathrm{T}$ cells and activation of a $\mathrm{T}$ cell population identified as $\mathrm{ICOS}^{+} \mathrm{CD} 4^{+}$Foxp $3^{+}$Tregs (146). 
In a Leishmania infection model in mice, it has been demonstrated that the absence of LCs leads to reduced Treg immigration, indicating a suppressive role of epidermal LCs through promotion of Tregs (147). Recently, the use of a transgenic mouse model has facilitated analysis of the immune functions of LCs in vivo without any alteration in the complex composition of skin DC subsets (148). When ovalbumin was presented by steadystate LCs or by activated LCs, they developed antigen-specific CTL tolerance due to an increase in Tregs or the CTL memory response, respectively. This decision-making depends on the condition of the presenting LCs.

All dermal cDCs are derived from hematopoietic stem cellderived progenitor $\mathrm{cDCs}$, pre-cDCs, that continuously repopulate the dermis. Mainly, four subsets of $\mathrm{cDCs}$ are resident in the dermis: langerin ${ }^{+} \mathrm{CD}_{103^{+}}$, langerin ${ }^{-} \mathrm{CD} 11 \mathrm{~b}^{+}$, langerin ${ }^{-} \mathrm{CD} 11 \mathrm{~b}^{-}$

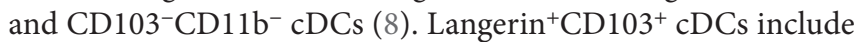
$10-20 \%$ dermal DCs and express XCR1. Langerin ${ }^{+} \mathrm{CD} 103^{+} \mathrm{cDCs}$ efficiently cross-present viral and self-antigens, and mice deficient in langerin ${ }^{+} \mathrm{CD} 103^{+}$show impaired priming of $\mathrm{CD} 8^{+} \mathrm{T}$ cells $(18,148,149)$. On the other hand, langerin ${ }^{+} \mathrm{CD}_{103^{+}} \mathrm{cDCs}$ are capable of generating Tregs (150). When langerin ${ }^{+} \mathrm{CD}_{103}{ }^{+}$ cDCs were depleted in Lang-DTR mice, anti-DE205-mediated antigen-specific delivery to DCs was no longer able to induce antigen-specific Tregs, resulting in loss of immune tolerance $(49,150)$. Human BDCA-3 $3^{+}$DCs, the counterpart of murine langerin ${ }^{+} \mathrm{CD} 103^{+} \mathrm{cDCs}$, have been shown to produce large amounts of IL-10 and to present self-antigens and induce Tregs (151). Langerin ${ }^{-} \mathrm{CD} 11 \mathrm{~b}^{+} \mathrm{cDCs}$ include $70-80 \%$ dermal DCs. Langerin ${ }^{-} \mathrm{CD} 11 \mathrm{~b}^{+} \mathrm{cDCs}$ can prime naïve $\mathrm{CD} 4^{+}$ $\mathrm{T}$ cells to undergo Th2 differentiation and play a role in the immune response through IL-23/IL-17 signaling (152-156). RA-producing CD $11 b^{+}$cDCs can induce Tregs upon migration to draining lymph nodes (157). Interestingly, it has recently been demonstrated that targeted deletion of IKK $\beta$, a major activator of NF- $\kappa \mathrm{B}$, in DCs prevents the accumulation of skin migratory DCs in draining lymph nodes under steady-state conditions, thus compromising Treg conversion (158). Thus, NF- $\kappa \mathrm{B}$ signaling appears to play a critical role in immunity and tolerance, as NF- $\kappa \mathrm{B}$ is a key regulator of TLR-induced DC maturation and production of pro-inflammatory cytokines. Taken together, the evidence suggests that LCs and dermal DCs play a pivotal role in not only the immune response but also immune tolerance in the skin.

\section{Intestine}

In the intestinal tract, IgA antibody production and the immune response by effector $\mathrm{T}$ cells are induced against pathogenic microorganisms. On the other hand, immune tolerance is also induced to avoid unnecessary inflammatory responses to food antigens and commensal bacteria. DCs play a critical role in the intestinal immune response and immune tolerance. In the intestinal mucosa, DCs are scattered diffusely throughout the intestinal lamina propria, within gut-associated lymphoid tissues including Peyer's patches and solitary intestinal lymphoid tissues (SILT), and also in intestinal draining lymph nodes such as MLNs $(159,160)$. Migration of intestinal DCs plays an important role in immune surveillance and homeostasis of the gut. Migratory intestinal DCs can be derived from three different sites: the lamina propria, Peyer's patches, and SILT presented within the small intestinal mucosa.

Themurinesmallintestinallaminapropria containsatleast three distinct populations of $\mathrm{cDCs}$ : $\mathrm{CD}_{103}{ }^{+} \mathrm{CD} 11 \mathrm{~b}^{-}, \mathrm{CD} 103^{+} \mathrm{CD} 11 \mathrm{~b}^{+}$,

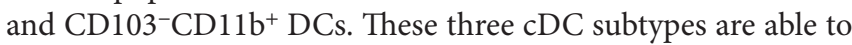
migrate via afferent lymphatics to the draining MLNs, a process that requires CCR7 signaling (161). cDCs in the lamina propria acquire antigens by handover, either from epithelial goblet cells or CX3CR $1^{\text {high }}$ macrophages $(162,163) . \mathrm{CD} 103^{+} \mathrm{CD} 11 \mathrm{~b}^{+} \mathrm{cDCs}$ in the lamina propria migrate into the epithelium and capture pathogenic bacteria presented in the gut lumen by extending their dendrites (164). Upon antigen uptake, lamina propria cDCs enter the $\mathrm{T}$ cell zone of gut-draining MLNs for DC-T cell interaction. Double negative CD103-CD11b- ${ }^{-}$DCs, which might exclusively originate from Peyer's patches and SILT, have also been reported to carry antigens via afferent lymphatics to MLNs (165).

For adaptive immunity, migratory DC subsets derived from the lamina propria show some specialization in the generation of distinct Th cell subsets. $\mathrm{CD} 103^{+} \mathrm{CD} 11 \mathrm{~b}^{+} \mathrm{cDC}$ activated with TLR produce high levels of IL- 6 and induce IL-6-dependent Th17 differentiation, while $\mathrm{CD} 103^{+} \mathrm{CD}_{11 b^{-}}$and $\mathrm{CD} 103^{-} \mathrm{CD} 11 \mathrm{~b}^{+} \mathrm{cDCs}$ can drive Th1 differentiation rather than $\mathrm{CD} 103^{+} \mathrm{CD} 11 \mathrm{~b}^{+} \mathrm{cDCs}$ (165-168). On the other hand, cDCs in the lamina propria and MLNs, especially the population of $\mathrm{CD} 103^{+} \mathrm{cDCs}$, play a central role in enforcing tolerance to food antigens and commensal bacteria under steady-state conditions. Many studies have shown that intestinal $\mathrm{CD} 103^{+} \mathrm{cDCs}$ highly induce Tregs through a mechanism mediated by TGF- $\beta$ and RA $(20,159,169)$. Tregs are induced by TGF- $\beta$, and RA enhances Treg induction only in the presence of TGF- $\beta$. TGF- $\beta$ is secreted by intestinal CD $103^{+} \mathrm{cDCs}$, Tregs, and intestinal stromal cells. Intestinal CD $103^{+} \mathrm{cDC}$ s highly express RALDH2, which convert vitamin A to RA, resulting in $\mathrm{RA}$ production from $\mathrm{CD} 103^{+} \mathrm{cDCs}$. In addition to Treg induction, RA also induces gut-homing receptors, CCR9 for the small intestinal chemokine CCL25 and $\alpha 4 \beta 7$ integrin for the mucosal vascular addressin, MAdCAM1. In addition, it has recently been demonstrated that RA acts cell intrinsically in developing guttropic pre-mucosal DCs to trigger differentiation and drive the specialist role of intestinal $\mathrm{CD}_{103}{ }^{+} \mathrm{CD} 11 \mathrm{~b}^{-}$and $\mathrm{CD} 103^{+} \mathrm{CD} 11 \mathrm{~b}^{+}$ cDCs (170). Overall, the evidence suggests that through production of RA and TGF- $\beta$, intestinal CD $103^{+} \mathrm{cDCs}$ induce the differentiation of Tregs and home them into the intestinal mucosa to control tolerance.

A conditional knockout approach allowing the deletion of specific subsets of $\mathrm{CD} 03^{+} \mathrm{cDCs}$ has demonstrated that intestinal $\mathrm{CD} 03^{+} \mathrm{CD} 11 \mathrm{~b}^{-} \mathrm{cDC}$ possess the greatest capacity to induce Treg differentiation, while $\mathrm{CD} 11 \mathrm{~b}^{+} \mathrm{DC}$ subsets are rather inefficient (65). Moreover, PD-L1 and PD-L2 expression by MNL DCs has been implicated in the induction of oral tolerance via regulation of the Treg compartment (171). Comparison among four distinct DC subsets in MLNs-CD $103^{+} \mathrm{CD} 11 \mathrm{~b}^{+} \mathrm{PD}$ $\mathrm{L}^{\text {high }}, \mathrm{CD} 103^{+} \mathrm{CD} 11 \mathrm{~b}^{-} \mathrm{PD}-\mathrm{L} 1^{\text {high }}, \mathrm{CD} 103^{+} \mathrm{CD} 11 \mathrm{~b}^{-\mathrm{PD}}-\mathrm{L} 1^{\text {low }}$, and $\mathrm{CD}_{103}{ }^{-} \mathrm{CD} 11 \mathrm{~b}^{+} \mathrm{PD}-\mathrm{L} 1^{\text {int }}$-has shown that $\mathrm{CD} 103^{+} \mathrm{CD} 11 \mathrm{~b}^{-} \mathrm{PD}-$ L1 ${ }^{\text {high }}$ DCs have a high capacity to induce Treg differentiation through TGF- $\beta$ signaling (172). It has been reported that $\alpha \mathrm{v} \beta 8$ integrin, an activator of latent TGF- $\beta$, is expressed preferentially on 


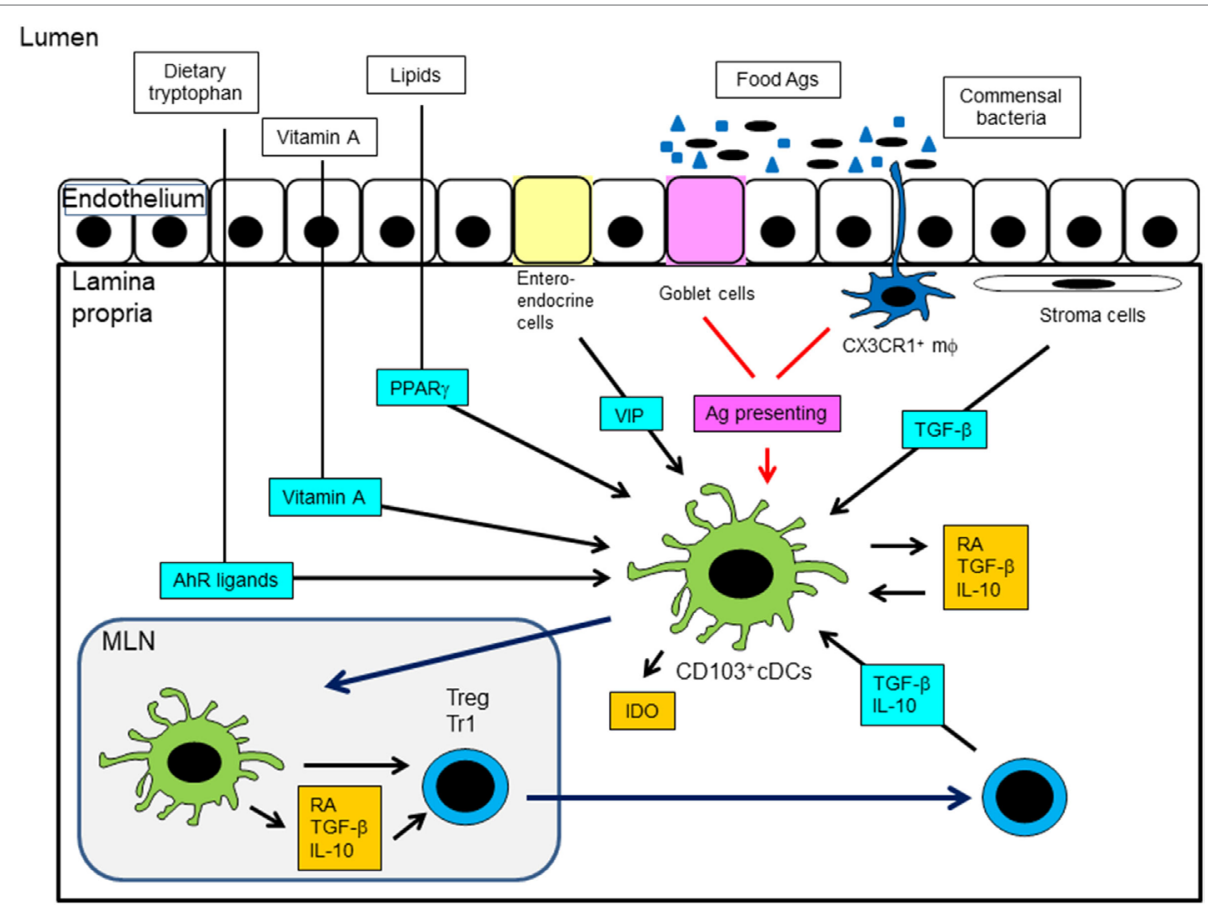

FIGURE 3 | Mechanisms of induction of tolerogenic DCs in the intestine. MLN, mesenteric lymph node; AhR, aryl hydrocarbon receptor; PPAR $\gamma$, peroxisome proliferator-activated receptor $\gamma$; VIP, vasoactive intestinal peptide; IDO, indoleamine 2,3-dioxygenase; RA, retinoic acid.

$\mathrm{CD}_{103}{ }^{+} \mathrm{CD} 11 \mathrm{~b}^{-} \mathrm{cDCs}$ in the lamina propria and MLNs and that $\alpha v \beta 8$ integrin-expressing DCs induce Tregs via TGF- $\beta$ activation (173). However, it remains unclear whether $\mathrm{CD}_{103}{ }^{+} \mathrm{CD} 11 \mathrm{~b}^{+}$ PD-L1 ${ }^{\text {high }}$ DCs and $\alpha v \beta 8$ integrin-expressing DCs represent the same population. Under steady-state conditions, $\mathrm{CD} 103^{+} \mathrm{cDCs}$ in the lamina propria are tolerogenic. In contrast, under inflammatory conditions, $\mathrm{CD}_{103}{ }^{+} \mathrm{cDCs}$ in the MLNs are immunogenic. $\mathrm{MLN} \mathrm{CD} 103^{+} \mathrm{cDCs}$ from colitic mice have been shown to trigger Th1 responses with high levels of IL-6 production (174). During intestinal inflammation, MLN CD103 ${ }^{+} \mathrm{cDCs}$ acquire these proinflammatory properties with no ontogenetic changes. Therefore, as well as DCs in the skin, $\mathrm{CD} 103^{+} \mathrm{cDCs}$ in the intestine can also be immunogenic or tolerogenic due to the microenvironment.

Some nutrients other than vitamin A are known to exert notable effects on intestinal tolerance. Tryptophan is a dietary element required for the IDO-dependent tolerogenic effects of intestinal DCs (175). Dietary tryptophan is metabolized into agonists for the aryl hydrocarbon receptor (AhR) through a series of cooperative biochemical reactions catalyzed by enzymes provided by gut commensal bacteria and the host (176). Tryptophan-derived AhR ligands induce the production of IL-10 and IL-27 by DCs, favoring the generation of Tregs and $\operatorname{Tr} 1$ cells. Diet-derived lipid mediators can activate peroxisome proliferator-activated receptor $\gamma$ (PPAR $\gamma$ ), and DCs exposed to PPAR $\gamma$ can be tolerogenic $(7,177)$. The gut mucosa is permeated by a complex nervous system and therefore exposed to the local release of neurotransmitters. Vasoactive intestinal peptide (VIP) is produced by intestinal enteroendocrine and immune cells and acts as a vasodilator and regulator of epithelial permeability. VIP suppresses LPS-induced DC maturation and promotes the differentiation of Tregs and
$\operatorname{Tr} 1$ cells $(178,179)$. Taken together, these findings suggest that metabolites provided by the diet and gut flora act in concert with endogenous signals to regulate the ability of DCs to control T cell responses and tissue homeostasis. Mechanisms of induction of tolDCs in the intestine are summarized in Figure 3.

\section{CONCLUSION}

Dendritic cells play a pivotal role in immune tolerance and homeostasis in the body. In this review, we present an overview of our current understanding of the mechanisms of tolerance induction by DCs in the body: DC origin, differentiation, and subsets; tolerance induction in the thymus and periphery; mechanisms of immune tolerance by DCs; and induction of immune tolerance by DCs in the skin and intestine. However, since analysis of the abovementioned mechanisms in health and disease is still insufficient, further studies are needed. A thorough understanding of the mechanisms that control immune tolerance will guide the development of novel strategies for the treatment of autoimmunity.

\section{AUTHOR CONTRIBUTIONS}

$\mathrm{HH}$ designed the study and drafted manuscript. TM edited the manuscript.

\section{FUNDING}

This work was supported by grants-in-aid (15K09551) for scientific research from the Ministry of Education, Culture, Sports, Science and Technology of Japan. 


\section{REFERENCES}

1. Iberg CA, Jones A, Hawiger D. Dendritic cells as inducers of peripheral tolerance. Trends Immunol (2017) 38(11):793-804. doi:10.1016/j.it.2017.07.007

2. Audiger C, Rahman MJ, Yun TJ, Tarbell KV, Lesage S. The importance of dendritic cells in maintaining immune tolerance. JImmunol (2017) 198(6):2223-31. doi:10.4049/jimmunol.1601629

3. Waisman A, Lukas D, Clausen BE, Yogev N. Dendritic cells as gatekeepers of tolerance. Semin Immunopathol (2017) 39(2):153-63. doi:10.1007/ s00281-016-0583-z

4. Horton C, Shanmugarajah K, Fairchild PJ. Harnessing the properties of dendritic cells in the pursuit of immunological tolerance. Biomed J (2017) 40(2):80-93. doi:10.1016/j.bj.2017.01.002

5. García-González P, Ubilla-Olguín G, Catalán D, Schinnerling K, Aguillón JC. Tolerogenic dendritic cells for reprogramming of lymphocyte responses in autoimmune diseases. Autoimmun Rev (2016) 15(11):1071-80. doi:10.1016/j. autrev.2016.07.032

6. Adnan E, Matsumoto T, Ishizaki J, Onishi S, Suemori K, Yasukawa M, et al. Human tolerogenic dendritic cells generated with protein kinase $\mathrm{C}$ inhibitor are optimal for functional regulatory $\mathrm{T}$ cell induction - a comparative study. Clin Immunol (2016) 173:96-108. doi:10.1016/j.clim.2016.09.007

7. Matsumoto T, Hasegawa H, Onishi S, Ishizaki J, Suemori K, Yasukawa M. Protein kinase $\mathrm{C}$ inhibitor generates stable human tolerogenic dendritic cells. J Immunol (2013) 191(5):2247-57. doi:10.4049/jimmunol.1203053

8. Worbs T, Hammerschmidt SI, Förster R. Dendritic cell migration in health and disease. Nat Rev Immunol (2017) 17(1):30-48. doi:10.1038/nri.2016.116

9. Haniffa M, Collin M, Ginhoux F. Ontogeny and functional specialization of dendritic cells in human and mouse. Adv Immunol (2013) 120:1-49. doi:10.1016/b978-0-12-417028-5.00001-6

10. Brasel K, De Smedt T, Smith JL, Maliszewski CR. Generation of murine dendritic cells from flt3-ligand-supplemented bone marrow cultures. Blood (2000) 96(9):3029-39.

11. Karsunky H, Merad M, Cozzio A, Weissman IL, Manz MG. Flt3 ligand regulates dendritic cell development from Flt3 $3^{+}$lymphoid and myeloidcommitted progenitors to Flt $3^{+}$dendritic cells in vivo. J Exp Med (2003) 198(2):305-13. doi:10.1084/jem.20030323

12. León B, López-Bravo M, Ardavín C. Monocyte-derived dendritic cells formed at the infection site control the induction of protective $\mathrm{T}$ helper 1 responses against Leishmania. Immunity (2007) 26(4):519-31. doi:10.1016/j. immuni.2007.01.017

13. Serbina NV, Salazar-Mather TP, Biron CA, Kuziel WA, Pamer EG. TNF/iNOS-producing dendritic cells mediate innate immune defense against bacterial infection. Immunity (2003) 19(1):59-70. doi:10.1016/ S1074-7613(03)00171-7

14. Haniffa M, Shin A, Bigley V, McGovern N, Teo P, See P, et al. Human tissues contain $\mathrm{CD} 14 \mathrm{1}^{\mathrm{hi}}$ cross-presenting dendritic cells with functional homology to mouse $\mathrm{CD}_{103^{+}}$nonlymphoid dendritic cells. Immunity (2012) 37(1):60-73. doi:10.1016/j.immuni.2012.04.012

15. Crozat K, Guiton R, Contreras V, Feuillet V, Dutertre CA, Ventre E, et al. The XC chemokine receptor 1 is a conserved selective marker of mammalian cells homologous to mouse CD8alpha ${ }^{+}$dendritic cells. J Exp Med (2010) 207(6):1283-92. doi:10.1084/jem.20100223

16. Caminschi I, Proietto AI, Ahmet F, Kitsoulis S, Shin Teh J, Lo JC, et al. The dendritic cell subtype-restricted C-type lectin Clec9A is a target for vaccine enhancement. Blood (2008) 112(8):3264-73. doi:10.1182/ blood-2008-05-155176

17. Huysamen C, Willment JA, Dennehy KM, Brown GD. CLEC9A is a novel activation C-type lectin-like receptor expressed on $\mathrm{BDCA}^{+}$dendritic cells and a subset of monocytes. J Biol Chem (2008) 283(24):16693-701. doi:10.1074/jbc.M709923200

18. Bedoui S, Whitney PG, Waithman J, Eidsmo L, Wakim L, Caminschi I, et al. Cross-presentation of viral and self antigens by skin-derived CD103 ${ }^{+}$dendritic cells. Nat Immunol (2009) 10(5):488-95. doi:10.1038/ ni. 1724

19. Mashayekhi M, Sandau MM, Dunay IR, Frickel EM, Khan A, Goldszmid RS, et al. CD8 $\alpha(+)$ dendritic cells are the critical source of interleukin-12 that controls acute infection by Toxoplasma gondii tachyzoites. Immunity (2011) 35(2):249-59. doi:10.1016/j.immuni.2011.08.008
20. Coombes JL, Siddiqui KR, Arancibia-Cárcamo CV, Hall J, Sun CM, Belkaid Y, et al. A functionally specialized population of mucosal $\mathrm{CD}_{103^{+}} \mathrm{DCs}$ induces Foxp $3^{+}$regulatory $\mathrm{T}$ cells via a TGF-beta and retinoic acid-dependent mechanism. JExp Med (2007) 204(8):1757-64. doi:10.1084/jem. 20070590

21. Schlitzer A, Ginhoux F. Organization of the mouse and human DC network. Curr Opin Immunol (2014) 26:90-9. doi:10.1016/j.coi.2013.11.002

22. Lewis KL, Caton ML, Bogunovic M, Greter M, Grajkowska LT, Ng D, et al. Notch2 receptor signaling controls functional differentiation of dendritic cells in the spleen and intestine. Immunity (2011) 35(5):780-91. doi:10.1016/j.immuni.2011.08.013

23. Dudziak D, Kamphorst AO, Heidkamp GF, Buchholz VR, Trumpfheller C, Yamazaki S, et al. Differential antigen processing by dendritic cell subsets in vivo. Science (2007) 315(5808):107-11. doi:10.1126/science.1136080

24. Sun CM, Hall JA, Blank RB, Bouladoux N, Oukka M, Mora JR, et al. Small intestine lamina propria dendritic cells promote de novo generation of Foxp3 T reg cells via retinoic acid. J Exp Med (2007) 204(8):1775-85. doi:10.1084/jem.20070602

25. Guilliams M, Crozat K, Henri S, Tamoutounour S, Grenot P, Devilard E, et al. Skin-draining lymph nodes contain dermis-derived CD103(-) dendritic cells that constitutively produce retinoic acid and induce Foxp3(+) regulatory T cells. Blood (2010) 115(10):1958-68. doi:10.1182/blood-2009-09245274

26. Reizis B, Bunin A, Ghosh HS, Lewis KL, Sisirak V. Plasmacytoid dendritic cells: recent progress and open questions. Annu Rev Immunol (2011) 29:163-83. doi:10.1146/annurev-immunol-031210-101345

27. Wakkach A, Fournier N, Brun V, Breittmayer JP, Cottrez F, Groux H. Characterization of dendritic cells that induce tolerance and T regulatory 1 cell differentiation in vivo. Immunity (2003) 18(5):605-17. doi:10.1016/ S1074-7613(03)00113-4

28. MosemanEA, LiangX, Dawson AJ, Panoskaltsis-Mortari A, Krieg AM,Liu YJ, et al. Human plasmacytoid dendritic cells activated by $\mathrm{CpG}$ oligodeoxynucleotides induce the generation of $\mathrm{CD}^{+} \mathrm{CD} 25^{+}$regulatory $\mathrm{T}$ cells. J Immunol (2004) 173(7):4433-42. doi:10.4049/jimmunol.173.7.4433

29. Oh J, Shin JS. The role of dendritic cells in central tolerance. Immune Netw (2015) 15(3):111-20. doi:10.4110/in.2015.15.3.111

30. Ohnmacht C, Pullner A, King SB, Drexler I, Meier S, Brocker T, et al. Constitutive ablation of dendritic cells breaks self-tolerance of CD4 $\mathrm{T}$ cells and results in spontaneous fatal autoimmunity. J Exp Med (2009) 206(3):549-59. doi:10.1084/jem.20082394

31. Vremec D, Pooley J, Hochrein H, Wu L, Shortman K. CD4 and CD8 expression by dendritic cell subtypes in mouse thymus and spleen. JImmunol (2000) 164(6):2978-86. doi:10.4049/jimmunol.164.6.2978

32. Porritt HE, Gordon K, Petrie HT. Kinetics of steady-state differentiation and mapping of intrathymic-signaling environments by stem cell transplantation in nonirradiated mice. J Exp Med (2003) 198(6):957-62. doi:10.1084/ jem.20030837

33. Atibalentja DF, Murphy KM, Unanue ER. Functional redundancy between thymic $\mathrm{CD} 8 \alpha^{+}$and Sirp $\alpha^{+}$conventional dendritic cells in presentation of blood-derived lysozyme by MHC class II proteins. J Immunol (2011) 186(3):1421-31. doi:10.4049/jimmunol.1002587

34. Ardouin L, Luche H, Chelbi R, Carpentier S, Shawket A, Montanana Sanchis F, et al. Broad and largely concordant molecular changes characterize tolerogenic and immunogenic dendritic cell maturation in thymus and periphery. Immunity (2016) 45(2):305-18. doi:10.1016/j.immuni.2016.07.019

35. Bonasio R, Scimone ML, Schaerli P, Grabie N, Lichtman AH, von Andrian UH. Clonal deletion of thymocytes by circulating dendritic cells homing to the thymus. Nat Immunol (2006) 7(10):1092-100. doi:10.1038/ni1385

36. Baba T, Nakamoto Y, Mukaida N. Crucial contribution of thymic Sirp alpha $^{+}$conventional dendritic cells to central tolerance against blood-borne antigens in a CCR2-dependent manner. J Immunol (2009) 183(5):3053-63. doi:10.4049/jimmunol.0900438

37. Proietto AI, van Dommelen S, Zhou P, Rizzitelli A, D’Amico A, Steptoe RJ, et al. Dendritic cells in the thymus contribute to T-regulatory cell induction. Proc Natl Acad Sci U S A (2008) 105(50):19869-74. doi:10.1073/ pnas. 0810268105

38. Coquet JM, Ribot JC, Babała N, Middendorp S, van der Horst G, Xiao Y, et al. Epithelial and dendritic cells in the thymic medulla promote $\mathrm{CD} 4^{+} \mathrm{Foxp}^{+}$ 
regulatory T cell development via the CD27-CD70 pathway. JExp Med (2013) 210(4):715-28. doi:10.1084/jem.20112061

39. Watanabe N, Wang YH, Lee HK, Ito T, Cao W, Liu YJ. Hassall's corpuscles instruct dendritic cells to induce $\mathrm{CD} 4^{+} \mathrm{CD} 25^{+}$regulatory T cells in human thymus. Nature (2005) 436(7054):1181-5. doi:10.1038/nature03886

40. Besin G, Gaudreau S, Ménard M, Guindi C, Dupuis G, Amrani A. Thymic stromal lymphopoietin and thymic stromal lymphopoietin-conditioned dendritic cells induce regulatory T-cell differentiation and protection of NOD mice against diabetes. Diabetes (2008) 57(8):2107-17. doi:10.2337/ db08-0171

41. Mazzucchelli R, Hixon JA, Spolski R, Chen X, Li WQ, Hall VL, et al. Development of regulatory T cells requires IL-7Ralpha stimulation by IL-7 or TSLP. Blood (2008) 112(8):3283-92. doi:10.1182/blood-2008-02-137414

42. Martín-Gayo E, Sierra-Filardi E, Corbí AL, Toribio ML. Plasmacytoid dendritic cells resident in human thymus drive natural Treg cell development. Blood (2010) 115(26):5366-75. doi:10.1182/blood-2009-10-248260

43. Hanabuchi S, Ito T, Park WR, Watanabe N, Shaw JL, Roman E, et al. Thymic stromal lymphopoietin-activated plasmacytoid dendritic cells induce the generation of FOXP $3^{+}$regulatory T cells in human thymus. J Immunol (2010) 184(6):2999-3007. doi:10.4049/jimmunol.0804106

44. Herbin O, Bonito AJ, Jeong S, Weinstein EG, Rahman AH, Xiong H, et al. Medullary thymic epithelial cells and CD $8 \alpha(+)$ dendritic cells coordinately regulate central tolerance but $\operatorname{CD} 8 \alpha(+)$ cells are dispensable for thymic regulatory T cell production. J Autoimmun (2016) 75:141-9. doi:10.1016/j. jaut.2016.08.002

45. Takaba H, Morishita Y, Tomofuji Y, Danks L, Nitta T, Komatsu N, et al. Fezf2 orchestrates a thymic program of self-antigen expression for immune tolerance. Cell (2015) 163(4):975-87. doi:10.1016/j.cell.2015.10.013

46. Lucas B, James KD, Cosway EJ, Parnell SM, Tumanov AV, Ware CF, et al. Lymphotoxin $\beta$ receptor controls $\mathrm{T}$ cell progenitor entry to the thymus. J Immunol (2016) 197(7):2665-72. doi:10.4049/jimmunol.1601189

47. Cosway EJ, Lucas B, James KD, Parnell SM, Carvalho-Gaspar M, White AJ, et al. Redefining thymus medulla specialization for central tolerance. J Exp Med (2017) 214(11):3183-95. doi:10.1084/jem.20171000

48. Devi KS, Anandasabapathy N. The origin of DCs and capacity for immunologic tolerance in central and peripheral tissues. Semin Immunopathol (2017) 39(2):137-52. doi:10.1007/s00281-016-0602-0

49. Idoyaga J, Fiorese C, Zbytnuik L, Lubkin A, Miller J, Malissen B, et al. Specialized role of migratory dendritic cells in peripheral tolerance induction. J Clin Invest (2013) 123(2):844-54. doi:10.1172/jci65260

50. Jonuleit H, Schmitt E, Schuler G, Knop J, Enk AH. Induction of interleukin 10-producing, nonproliferating CD4(+) T cells with regulatory properties by repetitive stimulation with allogeneic immature human dendritic cells. J Exp Med (2000) 192(9):1213-22. doi:10.1084/jem.192.9.1213

51. Levings MK, Gregori S, Tresoldi E, Cazzaniga S, Bonini C, Roncarolo MG. Differentiation of $\operatorname{Tr} 1$ cells by immature dendritic cells requires IL-10 but not $\mathrm{CD}_{2}{ }^{+} \mathrm{CD}^{+}$Tr cells. Blood (2005) 105(3):1162-9. doi:10.1182/ blood-2004-03-1211

52. Kushwah R, Wu J, Oliver JR, Jiang G, Zhang J, Siminovitch KA, et al. Uptake of apoptotic DC converts immature DC into tolerogenic DC that induce differentiation of Foxp3 ${ }^{+}$Treg. Eur J Immunol (2010) 40(4):1022-35. doi:10.1002/eji.200939782

53. Gleisner MA, Rosemblatt M, Fierro JA, Bono MR. Delivery of alloantigens via apoptotic cells generates dendritic cells with an immature tolerogenic phenotype. Transplant Proc (2011) 43(6):2325-33. doi:10.1016/j. transproceed.2011.06.007

54. Hegde S, Pahne J, Smola-Hess S. Novel immunosuppressive properties of interleukin-6 in dendritic cells: inhibition of NF-kappaB binding activity and CCR7 expression. FASEB J (2004) 18(12):1439-41. doi:10.1096/f.03-0969fje

55. Geisel J, Kahl F, Müller M, Wagner H, Kirschning CJ, Autenrieth IB, et al. IL-6 and maturation govern TLR2 and TLR4 induced TLR agonist tolerance and cross-tolerance in dendritic cells. J Immunol (2007) 179(9):5811-8. doi:10.4049/jimmunol.179.9.5811

56. Frick JS, Zahir N, Müller M, Kahl F, Bechtold O, Lutz MB, et al. Colitogenic and non-colitogenic commensal bacteria differentially trigger DC maturation and Th cell polarization: an important role for IL-6. Eur J Immunol (2006) 36(6):1537-47. doi:10.1002/eji.200635840

57. Steinbrink K, Wolfl M, Jonuleit $\mathrm{H}$, Knop J, Enk AH. Induction of tolerance by IL-10-treated dendritic cells. J Immunol (1997) 159(10):4772-80.
58. Menges M, Rossner S, Voigtlander C, Schindler H, Kukutsch NA, Bogdan C, et al. Repetitive injections of dendritic cells matured with tumor necrosis factor alpha induce antigen-specific protection of mice from autoimmunity. J Exp Med (2002) 195(1):15-21. doi:10.1084/jem.20011341

59. Lutz MB, Schuler G. Immature, semi-mature and fully mature dendritic cells: which signals induce tolerance or immunity? Trends Immunol (2002) 23(9):445-9. doi:10.1016/S1471-4906(02)02281-0

60. Knödler A, SchmidtSM, Bringmann A, WeckMM, Brauer KM, HolderriedTA, et al. Post-transcriptional regulation of adapter molecules by IL-10 inhibits TLR-mediated activation of antigen-presenting cells. Leukemia (2009) 23(3):535-44. doi:10.1038/leu.2008.301

61. Joffre OP, Sancho D, Zelenay S, Keller AM, Reis e Sousa C. Efficient and versatile manipulation of the peripheral $\mathrm{CD}^{+} \mathrm{T}$-cell compartment by antigen targeting to DNGR-1/CLEC9A. Eur J Immunol (2010) 40(5):1255-65. doi:10.1002/eji.201040419

62. Kretschmer K, Apostolou I, Hawiger D, Khazaie K, Nussenzweig MC, von Boehmer $\mathrm{H}$. Inducing and expanding regulatory $\mathrm{T}$ cell populations by foreign antigen. Nat Immunol (2005) 6(12):1219-27. doi:10.1038/ni1265

63. Ring S, Maas M, Nettelbeck DM, Enk AH, Mahnke K. Targeting of autoantigens to DEC205(+) dendritic cells in vivo suppresses experimental allergic encephalomyelitis in mice. J Immunol (2013) 191(6):2938-47. doi:10.4049/ jimmunol.1202592

64. Jones A, Bourque J, Kuehm L, Opejin A, Teague RM, Gross C, et al. Immunomodulatory functions of BTLA and HVEM govern induction of extrathymic regulatory $\mathrm{T}$ cells and tolerance by dendritic cells. Immunity (2016) 45(5):1066-77. doi:10.1016/j.immuni.2016.10.008

65. Esterházy D, Loschko J, London M, Jove V, Oliveira TY, Mucida D. Classical dendritic cells are required for dietary antigen-mediated induction of peripheral T(reg) cells and tolerance. Nat Immunol (2016) 17(5):545-55. doi:10.1038/ni.3408

66. Maggi J, Schafer C, Ubilla-Olguin G, Catalan D, Schinnerling K, Aguillon JC. Therapeutic potential of hyporesponsive $\mathrm{CD} 4(+) \mathrm{T}$ cells in autoimmunity. Front Immunol (2015) 6:488. doi:10.3389/fimmu.2015.00488

67. Kuklina EM. Molecular mechanisms of T-cell anergy. Biochemistry (Mosc) (2013) 78(2):144-56. doi:10.1134/S000629791302003X

68. Greenwald RJ, Boussiotis VA, Lorsbach RB, Abbas AK, Sharpe AH. CTLA-4 regulates induction of anergy in vivo. Immunity (2001) 14(2):145-55. doi:10.1016/S1074-7613(01)00097-8

69. Bishop KD, Harris JE, Mordes JP, Greiner DL, Rossini AA, Czech MP, et al. Depletion of the programmed death-1 receptor completely reverses established clonal anergy in CD4(+) T lymphocytes via an interleukin2-dependent mechanism. Cell Immunol (2009) 256(1-2):86-91. doi:10.1016/j. cellimm.2009.01.008

70. McBride JM, Jung T, de Vries JE, Aversa G. IL-10 alters DC function via modulation of cell surface molecules resulting in impaired T-cell responses. Cell Immunol (2002) 215(2):162-72. doi:10.1016/S0008-8749(02)00007-2

71. Tuettenberg A, Huter E, Hubo M, Horn J, Knop J, Grimbacher B, et al. The role of ICOS in directing T cell responses: ICOS-dependent induction of T cell anergy by tolerogenic dendritic cells. JImmunol (2009) 182(6):3349-56. doi:10.4049/jimmunol.0802733

72. Torres-Aguilar H, Aguilar-Ruiz SR, Gonzalez-Perez G, Munguia R, Bajana S, Meraz-Rios MA, et al. Tolerogenic dendritic cells generated with different immunosuppressive cytokines induce antigen-specific anergy and regulatory properties in memory CD4+ T cells. J Immunol (2010) 184(4):1765-75. doi:10.4049/jimmunol.0902133

73. Rodriguez E, Kalay H, Noya V, Brossard N, Giacomini C, van Kooyk Y, et al. Fasciola hepatica glycoconjugates immuneregulate dendritic cells through the Dendritic Cell-Specific Intercellular adhesion molecule-3-Grabbing Non-integrin inducing T cell anergy. Sci Rep (2017) 7:46748. doi:10.1038/ srep46748

74. Mueller DL. E3 ubiquitin ligases as T cell anergy factors. Nat Immunol (2004) 5(9):883-90. doi:10.1038/ni1106

75. Bachmaier K, Krawczyk C, Kozieradzki I, Kong YY, Sasaki T, Oliveirados-Santos A, et al. Negative regulation of lymphocyte activation and autoimmunity by the molecular adaptor Cbl-b. Nature (2000) 403(6766):211-6. doi:10.1038/35003228

76. Jeon MS, Atfield A, Venuprasad K, Krawczyk C, Sarao R, Elly C, et al. Essential role of the E3 ubiquitin ligase Cbl-b in T cell anergy induction. Immunity (2004) 21(2):167-77. doi:10.1016/j.immuni.2004.07.013 
77. Fang D, Elly C, Gao B, Fang N, Altman Y, Joazeiro C, et al. Dysregulation of T lymphocyte function in itchy mice: a role for Itch in TH2 differentiation. Nat Immunol (2002) 3(3):281-7. doi:10.1038/ni763

78. Heissmeyer V, Macian F, Im SH, Varma R, Feske S, Venuprasad K, et al. Calcineurin imposes $\mathrm{T}$ cell unresponsiveness through targeted proteolysis of signaling proteins. Nat Immunol (2004) 5(3):255-65. doi:10.1038/ni1047

79. Anandasabapathy N, Ford GS, Bloom D, Holness C, Paragas V, Seroogy C, et al. GRAIL: an E3 ubiquitin ligase that inhibits cytokine gene transcription is expressed in anergic CD4+ T cells. Immunity (2003) 18(4):535-47. doi:10.1016/S1074-7613(03)00084-0

80. Safford M, Collins S, Lutz MA, Allen A, Huang CT, Kowalski J, et al. Egr-2 and Egr-3 are negative regulators of T cell activation. Nat Immunol (2005) 6(5):472-80. doi:10.1038/ni1193

81. Harris JE, Bishop KD, Phillips NE, Mordes JP, Greiner DL, Rossini AA, et al. Early growth response gene-2, a zinc-finger transcription factor, is required for full induction of clonal anergy in CD4+ T cells. JImmunol (2004) 173(12):7331-8. doi:10.4049/jimmunol.173.12.7331

82. Collins S, Lutz MA, Zarek PE, Anders RA, Kersh GJ, Powell JD. Opposing regulation of T cell function by Egr-1/NAB2 and Egr-2/Egr-3. Eur J Immunol (2008) 38(2):528-36. doi:10.1002/eji.200737157

83. Buer J, Lanoue A, Franzke A, Garcia C, von Boehmer H, Sarukhan A. Interleukin 10 secretion and impaired effector function of major histocompatibility complex class II-restricted T cells anergized in vivo. J Exp Med (1998) 187(2):177-83. doi:10.1084/jem.187.2.177

84. Steinbrink K, Graulich E, Kubsch S, Knop J, Enk AH. CD4(+) and CD8(+) anergic $\mathrm{T}$ cells induced by interleukin-10-treated human dendritic cells display antigen-specific suppressor activity. Blood (2002) 99(7):2468-76. doi:10.1182/blood.V99.7.2468

85. Kubsch S, Graulich E, Knop J, Steinbrink K. Suppressor activity of anergic $\mathrm{T}$ cells induced by IL-10-treated human dendritic cells: association with IL-2- and CTLA-4-dependent G1 arrest of the cell cycle regulated by p27Kip1. Eur J Immunol (2003) 33(7):1988-97. doi:10.1002/eji.200323600

86. Pletinckx K, Vaeth M, Schneider T, Beyersdorf N, Hunig T, Berberich-Siebelt F, et al. Immature dendritic cells convert anergic nonregulatory $\mathrm{T}$ cells into Foxp3- IL-10+ regulatory T cells by engaging CD28 and CTLA-4. Eur J Immunol (2015) 45(2):480-91. doi:10.1002/eji.201444991

87. Hawiger D, Inaba K, Dorsett Y, Guo M, Mahnke K, Rivera M, et al. Dendritic cells induce peripheral $\mathrm{T}$ cell unresponsiveness under steady state conditions in vivo. J Exp Med (2001) 194(6):769-79. doi:10.1084/jem.194.6.769

88. Dunkle A, He YW. Apoptosis and autophagy in the regulation of T lymphocyte function. Immunol Res (2011) 49(1-3):70-86. doi:10.1007/ s12026-010-8195-5

89. Gronski MA, Weinem M. Death pathways in T cell homeostasis and their role in autoimmune diabetes. Rev Diabet Stud (2006) 3(2):88-95. doi:10.1900/ RDS.2006.3.88

90. Süss G, Shortman K. A subclass of dendritic cells kills CD4 T cells via Fas/ Fas-ligand-induced apoptosis. J Exp Med (1996) 183(4):1789-96. doi:10.1084/jem.183.4.1789

91. Fanger NA, Maliszewski CR, Schooley K, Griffith TS. Human dendritic cells mediate cellular apoptosis via tumor necrosis factor-related apoptosisinducing ligand (TRAIL). J Exp Med (1999) 190(8):1155-64. doi:10.1084/ jem.190.8.1155

92. Grohmann U, Fallarino F, Bianchi R, Belladonna ML, Vacca C, Orabona C, et al. IL- 6 inhibits the tolerogenic function of CD8 alpha ${ }^{+}$dendritic cells expressing indoleamine 2,3-dioxygenase. J Immunol (2001) 167(2):708-14. doi:10.4049/jimmunol.167.2.708

93. Hwu P, Du MX, Lapointe R, Do M, Taylor MW, Young HA. Indoleamine 2,3-dioxygenase production by human dendritic cells results in the inhibition of T cell proliferation. J Immunol (2000) 164(7):3596-9. doi:10.4049/ jimmunol.164.7.3596

94. Qian C, Qian L, Yu Y, An H, Guo Z, Han Y, et al. Fas signal promotes the immunosuppressive function of regulatory dendritic cells via the ERK/ $\beta$ catenin pathway. J Biol Chem (2013) 288(39):27825-35. doi:10.1074/jbc. M112.425751

95. Izawa T, Kondo T, Kurosawa M, Oura R, Matsumoto K, Tanaka E, et al. Fas-independent T-cell apoptosis by dendritic cells controls autoimmune arthritis in MRL/lpr mice. PLoS One (2012) 7(12):e48798. doi:10.1371/ journal.pone.0048798
96. Jürgens B, Hainz U, Fuchs D, Felzmann T, Heitger A. Interferongamma-triggered indoleamine 2,3-dioxygenase competence in human monocyte-derived dendritic cells induces regulatory activity in allogeneic T cells. Blood (2009) 114(15):3235-43. doi:10.1182/blood-2008-12-195073

97. Munn DH, Mellor AL. Indoleamine 2,3 dioxygenase and metabolic control of immune responses. Trends Immunol (2013) 34(3):137-43. doi:10.1016/j. it.2012.10.001

98. Matteoli G, Mazzini E, Iliev ID, Mileti E, Fallarino F, Puccetti P, et al. Gut CD103+ dendritic cells express indoleamine 2,3-dioxygenase which influences $\mathrm{T}$ regulatory/T effector cell balance and oral tolerance induction. Gut (2010) 59(5):595-604. doi:10.1136/gut.2009.185108

99. Brenk M, Scheler M, Koch S, Neumann J, Takikawa O, Häcker G, et al. Tryptophan deprivation induces inhibitory receptors ILT3 and ILT4 on dendritic cells favoring the induction of human CD $4^{+} \mathrm{CD} 25^{+} \mathrm{Foxp} 3^{+} \mathrm{T}$ regulatory cells. J Immunol (2009) 183(1):145-54. doi:10.4049/jimmunol 0803277

100. Wada J, Ota K, Kumar A, Wallner EI, Kanwar YS. Developmental regulation, expression, and apoptotic potential of galectin-9, a beta-galactoside binding lectin. J Clin Invest (1997) 99(10):2452-61. doi:10.1172/JCI119429

101. Kashio Y, Nakamura K, Abedin MJ, Seki M, Nishi N, Yoshida N, et al. Galectin-9 induces apoptosis through the calcium-calpain-caspase-1 pathway. J Immunol (2003) 170(7):3631-6. doi:10.4049/jimmunol.170.7.3631

102. Seki M, Oomizu S, Sakata KM, Sakata A, Arikawa T, Watanabe K, et al. Galectin-9 suppresses the generation of Th17, promotes the induction of regulatory $\mathrm{T}$ cells, and regulates experimental autoimmune arthritis. Clin Immunol (2008) 127(1):78-88. doi:10.1016/j.clim.2008.01.006

103. Mobergslien A, Sioud M. Galectin-1 and -3 gene silencing in immature and mature dendritic cells enhances $\mathrm{T}$ cell activation and interferon-gamma production. J Leukoc Biol (2012) 91(3):461-7. doi:10.1189/jlb.0711361

104. Zhu C, Anderson AC, Schubart A, Xiong H, Imitola J, Khoury SJ, et al. The Tim-3 ligand galectin-9 negatively regulates T helper type 1 immunity. Nat Immunol (2005) 6(12):1245-52. doi:10.1038/ni1271

105. Wells AD, Li XC, Li Y, Walsh MC, Zheng XX, Wu Z, et al. Requirement for T-cell apoptosis in the induction of peripheral transplantation tolerance. Nat Med (1999) 5(11):1303-7. doi:10.1038/15260

106. Wekerle T, Kurtz J, Sayegh M, Ito H, Wells A, Bensinger S, et al. Peripheral deletion after bone marrow transplantation with costimulatory blockade has features of both activation-induced cell death and passive cell death. J Immunol (2001) 166(4):2311-6. doi:10.4049/jimmunol.166.4.2311

107. Cippa PE, Gabriel SS, Chen J, Bardwell PD, Bushell A, Guimezanes A, et al. Targeting apoptosis to induce stable mixed hematopoietic chimerism and long-term allograft survival without myelosuppressive conditioning in mice. Blood (2013) 122(9):1669-77. doi:10.1182/blood-2012-09-453944

108. Zuber J, Sykes M. Mechanisms of mixed chimerism-based transplant tolerance. Trends Immunol (2017) 38(11):829-43. doi:10.1016/j.it.2017.07.008

109. Bouillet P, Purton JF, Godfrey DI, Zhang LC, Coultas L, Puthalakath H, et al. BH3-only Bcl-2 family member Bim is required for apoptosis of autoreactive thymocytes. Nature (2002) 415(6874):922-6. doi:10.1038/415922a

110. Davey GM, Kurts C, Miller JF, Bouillet P, Strasser A, Brooks AG, et al. Peripheral deletion of autoreactive CD8 $\mathrm{T}$ cells by cross presentation of self-antigen occurs by a Bcl-2-inhibitable pathway mediated by Bim. J Exp Med (2002) 196(7):947-55. doi:10.1084/jem.20020827

111. Salomon B, Lenschow DJ, Rhee L, Ashourian N, Singh B, Sharpe A, et al. $\mathrm{B} 7 / \mathrm{CD} 28$ costimulation is essential for the homeostasis of the CD $4{ }^{+} \mathrm{CD} 25^{+}$ immunoregulatory $\mathrm{T}$ cells that control autoimmune diabetes. Immunity (2000) 12(4):431-40. doi:10.1016/S1074-7613(00)80195-8

112. Bar-On L, Birnberg T, Kim KW, Jung S. Dendritic cell-restricted CD80/86 deficiency results in peripheral regulatory T-cell reduction but is not associated with lymphocyte hyperactivation. Eur J Immunol (2011) 41(2):291-8. doi:10.1002/eji.201041169

113. Akbari O, Freeman GJ, Meyer EH, Greenfield EA, Chang TT, Sharpe AH, et al. Antigen-specific regulatory T cells develop via the ICOS-ICOS-ligand pathway and inhibit allergen-induced airway hyperreactivity. Nat Med(2002) 8(9):1024-32. doi:10.1038/nm745

114. Manavalan JS, Rossi PC, Vlad G, Piazza F, Yarilina A, Cortesini R, et al. High expression of ILT3 and ILT4 is a general feature of tolerogenic dendritic cells. Transpl Immunol (2003) 11(3-4):245-58. doi:10.1016/ s0966-3274(03)00058-3 
115. Wang L, Pino-Lagos K, de Vries VC, Guleria I, Sayegh MH, Noelle RJ. Programmed death 1 ligand signaling regulates the generation of adaptive Foxp3+CD4+ regulatory T cells. Proc Natl Acad Sci U S A (2008) 105(27):9331-6. doi:10.1073/pnas.0710441105

116. Francisco LM, Salinas VH, Brown KE, Vanguri VK, Freeman GJ, Kuchroo VK, et al. PD-L1 regulates the development, maintenance, and function of induced regulatory T cells. J Exp Med (2009) 206(13):3015-29. doi:10.1084/ jem. 20090847

117. Fife BT, Pauken KE, Eagar TN, Obu T, Wu J, Tang Q, et al. Interactions between PD-1 and PD-L1 promote tolerance by blocking the TCR-induced stop signal. Nat Immunol (2009) 10(11):1185-92. doi:10.1038/ni.1790

118. Henderson JG, Opejin A, Jones A, Gross C, Hawiger D. CD5 instructs extrathymic regulatory $\mathrm{T}$ cell development in response to self and tolerizing antigens. Immunity (2015) 42(3):471-83. doi:10.1016/j.immuni.2015. 02.010

119. Keir ME, Francisco LM, Sharpe AH. PD-1 and its ligands in T-cell immunity. Curr Opin Immunol (2007) 19(3):309-14. doi:10.1016/j.coi.2007.04.012

120. Schmidt M, Lügering N, Pauels HG, Schulze-Osthoff K, Domschke W, Kucharzik T. IL-10 induces apoptosis in human monocytes involving the CD95 receptor/ligand pathway. Eur J Immunol (2000) 30(6):1769-77. doi:10.1002/1521-4141(200006)30:6<1769::aid-immu1769>3.0.co;2-9

121. Chen W, Jin W, Hardegen N, Lei KJ, Li L, Marinos N, et al. Conversion of peripheral $\mathrm{CD}^{+} \mathrm{CD} 25^{-}$naive $\mathrm{T}$ cells to $\mathrm{CD} 4^{+} \mathrm{CD} 25^{+}$regulatory $\mathrm{T}$ cells by TGF-beta induction of transcription factor Foxp3. J Exp Med (2003) 198(12):1875-86. doi:10.1084/jem.20030152

122. Yamazaki S, Bonito AJ, Spisek R, Dhodapkar M, Inaba K, Steinman RM. Dendritic cells are specialized accessory cells along with TGF- for the differentiation of Foxp3+ CD4+ regulatory $\mathrm{T}$ cells from peripheral Foxp3 precursors. Blood (2007) 110(13):4293-302. doi:10.1182/blood2007-05-088831

123. Awasthi A, Carrier Y, Peron JP, Bettelli E, Kamanaka M, Flavell RA, et al. A dominant function for interleukin 27 in generating interleukin 10producing anti-inflammatory T cells. Nat Immunol (2007) 8(12):1380-9. doi:10.1038/ni1541

124. Sweeney CM, Lonergan R, Basdeo SA, Kinsella K, Dungan LS, Higgins SC, et al. IL-27 mediates the response to IFN- $\beta$ therapy in multiple sclerosis patients by inhibiting Th17 cells. Brain Behav Immun (2011) 25(6):1170-81. doi:10.1016/j.bbi.2011.03.007

125. Wang H, Meng R, Li Z, Yang B, Liu Y, Huang F, et al. IL-27 induces the differentiation of $\operatorname{Tr} 1$-like cells from human naive $\mathrm{CD} 4^{+} \mathrm{T}$ cells via the phosphorylation of STAT1 and STAT3. Immunol Lett (2011) 136(1):21-8. doi:10.1016/j.imlet.2010.11.007

126. Mascanfroni ID, Yeste A, Vieira SM, Burns EJ, Patel B, Sloma I, et al. IL-27 acts on DCs to suppress the $\mathrm{T}$ cell response and autoimmunity by inducing expression of the immunoregulatory molecule CD39. Nat Immunol (2013) 14(10):1054-63. doi:10.1038/ni.2695

127. Iwata M, Hirakiyama A, Eshima Y, Kagechika H, Kato C, Song SY. Retinoic acid imprints gut-homing specificity on T cells. Immunity (2004) 21(4): 527-38. doi:10.1016/j.immuni.2004.08.011

128. Mucida D, Park Y, Kim G, Turovskaya O, Scott I, Kronenberg M, et al. Reciprocal TH17 and regulatory T cell differentiation mediated by retinoic acid. Science (2007) 317(5835):256-60. doi:10.1126/science.1145697

129. Dixon KO, van der Kooij SW, Vignali DA, van Kooten C. Human tolerogenic dendritic cells produce IL-35 in the absence of other IL-12 family members. Eur J Immunol (2015) 45(6):1736-47. doi:10.1002/eji.201445217

130. Haller S, Duval A, Migliorini R, Stevanin M, Mack V, Acha-Orbea H. Interleukin-35-producing CD8alpha(+) dendritic cells acquire a tolerogenic state and regulate T cell function. Front Immunol (2017) 8:98. doi:10.3389/ fimmu.2017.00098

131. Collison LW, Workman CJ, Kuo TT, Boyd K, Wang Y, Vignali KM, et al. The inhibitory cytokine IL-35 contributes to regulatory T-cell function. Nature (2007) 450(7169):566-9. doi:10.1038/nature06306

132. Niedbala W, Wei XQ, Cai B, Hueber AJ, Leung BP, McInnes IB, et al. IL-35 is a novel cytokine with therapeutic effects against collagen-induced arthritis through the expansion of regulatory T cells and suppression of Th17 cells. Eur J Immunol (2007) 37(11):3021-9. doi:10.1002/eji.200737810

133. Wang RX, Yu CR, Dambuza IM, Mahdi RM, Dolinska MB, Sergeev YV, et al. Interleukin-35 induces regulatory B cells that suppress autoimmune disease. Nat Med (2014) 20(6):633-41. doi:10.1038/nm.3554
134. Shen P, Roch T, Lampropoulou V, O’Connor RA, Stervbo U, Hilgenberg E, et al. IL-35-producing B cells are critical regulators of immunity during autoimmune and infectious diseases. Nature (2014) 507(7492):366-70. doi:10.1038/nature12979

135. Guan SY, Leng RX, Khan MI, Qureshi H, Li XP, Ye DQ, et al. Interleukin-35: a potential therapeutic agent for autoimmune diseases. Inflammation (2017) 40(1):303-10. doi:10.1007/s10753-016-0453-9

136. Whitehead GS, Wilson RH, Nakano K, Burch LH, Nakano H, Cook DN. IL35 production by inducible costimulator (ICOS)-positive regulatory T cells reverses established IL-17-dependent allergic airways disease. J Allergy Clin Immunol (2012) 129(1):207-15.e1-5. doi:10.1016/j.jaci.2011.08.009

137. Kohli K, Janssen A, Förster R. Plasmacytoid dendritic cells induce tolerance predominantly by cargoing antigen to lymph nodes. Eur J Immunol (2016) 46(11):2659-68. doi:10.1002/eji.201646359

138. Manches O, Munn D, Fallahi A, Lifson J, Chaperot L, Plumas J, et al. HIVactivated human plasmacytoid DCs induce Tregs through an indoleamine 2,3-dioxygenase-dependent mechanism. J Clin Invest (2008) 118(10):3431-9. doi: $10.1172 /$ jci34823

139. Mahnke K, Johnson TS, Ring S, Enk AH. Tolerogenic dendritic cells and regulatory T cells: a two-way relationship. JDermatol Sci (2007) 46(3):159-67. doi:10.1016/j.jdermsci.2007.03.002

140. Yan J, Liu B, Shi Y, Qi H. Class II MHC-independent suppressive adhesion of dendritic cells by regulatory T cells in vivo. J Exp Med (2017) 214(2):319-26. doi:10.1084/jem.20160629

141. Chen J, Ganguly A, Mucsi AD, Meng J, Yan J, Detampel P, et al. Strong adhesion by regulatory $\mathrm{T}$ cells induces dendritic cell cytoskeletal polarization and contact-dependent lethargy. J Exp Med (2017) 214(2):327-38. doi:10.1084/jem.20160620

142. Clausen BE, Stoitzner P. Functional specialization of skin dendritic cell subsets in regulating T cell responses. Front Immunol (2015) 6:534. doi:10.3389/ fimmu.2015.00534

143. Igyártó BZ, Haley K, Ortner D, Bobr A, Gerami-Nejad M, Edelson BT, et al. Skin-resident murine dendritic cell subsets promote distinct and opposing antigen-specific T helper cell responses. Immunity (2011) 35(2):260-72. doi:10.1016/j.immuni.2011.06.005

144. Nakajima S, Igyártó BZ, Honda T, Egawa G, Otsuka A, Hara-Chikuma M, et al. Langerhans cells are critical in epicutaneous sensitization with protein antigen via thymic stromal lymphopoietin receptor signaling. J Allergy Clin Immunol (2012) 129(4):1048-55.e6. doi:10.1016/j.jaci.2012.01.063

145. Igyarto BZ, Jenison MC, Dudda JC, Roers A, Müller W, Koni PA, et al. Langerhans cells suppress contact hypersensitivity responses via cognate CD4 interaction and Langerhans cell-derived IL-10. J Immunol (2009) 183(8):5085-93. doi:10.4049/jimmunol.0901884

146. Gomez de Agüero M, Vocanson M, Hacini-Rachinel F, Taillardet M, Sparwasser T, Kissenpfennig A, et al. Langerhans cells protect from allergic contact dermatitis in mice by tolerizing $\mathrm{CD} 8(+) \mathrm{T}$ cells and activating Foxp3(+) regulatory T cells. J Clin Invest (2012) 122(5):1700-11. doi:10.1172/ jci59725

147. Kautz-Neu K, Noordegraaf M, Dinges S, Bennett CL, John D, Clausen BE, et al. Langerhans cells are negative regulators of the anti-Leishmania response. J Exp Med (2011) 208(5):885-91. doi:10.1084/jem.20102318

148. Strandt H, Pinheiro DF, Kaplan DH, Wirth D, Gratz IK, Hammerl P, et al. Neoantigen expression in steady-state Langerhans cells induces CTL tolerance. J Immunol (2017) 199(5):1626-34. doi:10.4049/jimmunol.1602098

149. Henri S, Poulin LF, Tamoutounour S, Ardouin L, Guilliams M, de Bovis $\mathrm{B}$, et al. $\mathrm{CD} 207^{+} \mathrm{CD} 103^{+}$dermal dendritic cells cross-present keratinocytederived antigens irrespective of the presence of Langerhans cells. J Exp Med (2010) 207(1):189-206. doi:10.1084/jem.20091964

150. Murphy TL, Tussiwand R, Murphy KM. Specificity through cooperation: BATF-IRF interactions control immune-regulatory networks. Nat Rev Immunol (2013) 13(7):499-509. doi:10.1038/nri3470

151. Chu CC, Ali N, Karagiannis P, Di Meglio P, Skowera A, Napolitano L, et al. Resident CD141 (BDCA3) ${ }^{+}$dendritic cells in human skin produce IL-10 and induce regulatory $\mathrm{T}$ cells that suppress skin inflammation. J Exp Med (2012) 209(5):935-45. doi:10.1084/jem.20112583

152. Mollah SA, Dobrin JS, Feder RE, Tse SW, Matos IG, Cheong C, et al. Flt3L dependence helps define an uncharacterized subset of murine cutaneous dendritic cells. J Invest Dermatol (2014) 134(5):1265-75. doi:10.1038/ jid.2013.515 
153. Kitajima M, Ziegler SF. Cutting edge: identification of the thymic stromal lymphopoietin-responsive dendritic cell subset critical for initiation of type 2 contact hypersensitivity. J Immunol (2013) 191(10):4903-7. doi:10.4049/ jimmunol.1302175

154. Kumamoto Y, Linehan M, Weinstein JS, Laidlaw BJ, Craft JE, Iwasaki A. CD301b+ dermal dendritic cells drive T helper 2 cell-mediated immunity. Immunity (2013) 39(4):733-43. doi:10.1016/j.immuni.2013.08.029

155. Wohn C, Ober-Blöbaum JL, Haak S, Pantelyushin S, Cheong C, Zahner SP, et al. Langerin(neg) conventional dendritic cells produce IL-23 to drive psoriatic plaque formation in mice. Proc Natl Acad Sci U S A (2013) 110(26):10723-8. doi:10.1073/pnas.1307569110

156. Yoshiki R, Kabashima K, Honda T, Nakamizo S, Sawada Y, Sugita K, et al. IL-23 from Langerhans cells is required for the development of imiquimod-induced psoriasis-like dermatitis by induction of IL-17A-producing $\gamma \delta$ T cells. J Invest Dermatol (2014) 134(7):1912-21. doi:10.1038/jid.2014.98

157. Tanaka Y, Nagashima H, Bando K, Lu L, Ozaki A, Morita Y, et al. Oral CD103(-)CD11b(+) classical dendritic cells present sublingual antigen and induce Foxp3(+) regulatory T cells in draining lymph nodes. Mucosal Immunol (2017) 10(1):79-90. doi:10.1038/mi.2016.46

158. Baratin M, Foray C, Demaria O, Habbeddine M, Pollet E, Maurizio J, et al. Homeostatic NF- $\mathrm{BB}$ signaling in steady-state migratory dendritic cells regulates immune homeostasis and tolerance. Immunity (2015) 42(4):627-39. doi:10.1016/j.immuni.2015.03.003

159. Aliberti J. Immunity and tolerance induced by intestinal mucosal dendritic cells. Mediators Inflamm (2016) 2016:3104727. doi:10.1155/2016/3104727

160. Bekiaris V, Persson EK, Agace WW. Intestinal dendritic cells in the regulation of mucosal immunity. Immunol Rev (2014) 260(1):86-101. doi:10.1111/ imr.12194

161. Pabst O, Herbrand H, Friedrichsen M, Velaga S, Dorsch M, Berhardt G, et al. Adaptation of solitary intestinal lymphoid tissue in response to microbiota and chemokine receptor CCR7 signaling. J Immunol (2006) 177(10):6824-32. doi:10.4049/jimmunol.177.10.6824

162. Niess JH, Brand S, Gu X, Landsman L, Jung S, McCormick BA, et al. CX3CR1-mediated dendritic cell access to the intestinal lumen and bacterial clearance. Science (2005) 307(5707):254-8. doi:10.1126/science.1102901

163. McDole JR, Wheeler LW, McDonald KG, Wang B, Konjufca V, Knoop KA, et al. Goblet cells deliver luminal antigen to $\mathrm{CD}_{103^{+}}$dendritic cells in the small intestine. Nature (2012) 483(7389):345-9. doi:10.1038/nature10863

164. Farache J, Koren I, Milo I, Gurevich I, Kim KW, Zigmond E, et al. Luminal bacteria recruit $\mathrm{CD}_{103}{ }^{+}$dendritic cells into the intestinal epithelium to sample bacterial antigens for presentation. Immunity (2013) 38(3):581-95. doi:10.1016/j.immuni.2013.01.009

165. Cerovic V, Houston SA, Scott CL, Aumeunier A, Yrlid U, Mowat AM, et al. Intestinal CD103(-) dendritic cells migrate in lymph and prime effector T cells. Mucosal Immunol (2013) 6(1):104-13. doi:10.1038/mi.2012.53

166. Denning TL, Norris BA, Medina-Contreras O, Manicassamy S, Geem D, Madan R, et al. Functional specializations of intestinal dendritic cell and macrophage subsets that control Th17 and regulatory $\mathrm{T}$ cell responses are dependent on the T cell/APC ratio, source of mouse strain, and regional localization. J Immunol (2011) 187(2):733-47. doi:10.4049/jimmunol.1002701

167. Fujimoto K, Karuppuchamy T, Takemura N, Shimohigoshi M, Machida T, Haseda Y, et al. A new subset of $\mathrm{CD} 03^{+} \mathrm{CD} 8 \mathrm{alpha}{ }^{+}$dendritic cells in the small intestine expresses TLR3, TLR7, and TLR9 and induces Th1 response and CTL activity. J Immunol (2011) 186(11):6287-95. doi:10.4049/ jimmunol.1004036

168. Persson EK, Uronen-Hansson H, Semmrich M, Rivollier A, Hägerbrand K, Marsal J, et al. IRF4 transcription-factor-dependent CD103(+)CD11b(+) dendritic cells drive mucosal $\mathrm{T}$ helper 17 cell differentiation. Immunity (2013) 38(5):958-69. doi:10.1016/j.immuni.2013.03.009

169. Scott CL, Aumeunier AM, Mowat AM. Intestinal $\mathrm{CD} 103^{+}$dendritic cells: master regulators of tolerance? Trends Immunol (2011) 32(9):412-9. doi:10.1016/j.it.2011.06.003

170. Zeng R, Bscheider M, Lahl K, Lee M, Butcher EC. Generation and transcriptional programming of intestinal dendritic cells: essential role of retinoic acid. Mucosal Immunol (2016) 9(1):183-93. doi:10.1038/mi.2015.50

171. Fukaya T, Takagi H, Sato Y, Sato K, Eizumi K, Taya H, et al. Crucial roles of B7-H1 and B7-DC expressed on mesenteric lymph node dendritic cells in the generation of antigen-specific $\mathrm{CD} 4^{+} \mathrm{Foxp} 3^{+}$regulatory $\mathrm{T}$ cells in the establishment of oral tolerance. Blood (2010) 116(13):2266-76. doi:10.1182/ blood-2009-10-250472

172. Shiokawa A, Kotaki R, Takano T, Nakajima-Adachi H, Hachimura S. Mesenteric lymph node CD11b(-) CD103(+) PD-L1(High) dendritic cells highly induce regulatory T cells. Immunology (2017) 152(1):52-64. doi:10.1111/imm.12747

173. Boucard-Jourdin M, Kugler D, Endale Ahanda ML, This S, De Calisto J, Zhang A, et al. $\beta 8$ integrin expression and activation of TGF- $\beta$ by intestinal dendritic cells are determined by both tissue microenvironment and cell lineage. J Immunol (2016) 197(5):1968-78. doi:10.4049/jimmunol. 1600244

174. Laffont S, Siddiqui KR, Powrie F. Intestinal inflammation abrogates the tolerogenic properties of MLN CD103+ dendritic cells. Eur J Immunol (2010) 40(7):1877-83. doi:10.1002/eji.200939957

175. Fallarino F, Grohmann U, You S, McGrath BC, Cavener DR, Vacca C, et al. The combined effects of tryptophan starvation and tryptophan catabolites down-regulate $\mathrm{T}$ cell receptor zeta-chain and induce a regulatory phenotype in naive T cells. J Immunol (2006) 176(11):6752-61. doi:10.4049/ jimmunol.176.11.6752

176. Zelante T, Iannitti RG, Cunha C, De Luca A, Giovannini G, Pieraccini G, et al. Tryptophan catabolites from microbiota engage aryl hydrocarbon receptor and balance mucosal reactivity via interleukin-22. Immunity (2013) 39(2):372-85. doi:10.1016/j.immuni.2013.08.003

177. Klotz L, Dani I, Edenhofer F, Nolden L, Evert B, Paul B, et al. Peroxisome proliferator-activated receptor gamma control of dendritic cell function contributes to development of CD4+ T cell anergy. J Immunol (2007) 178(4):2122-31. doi:10.4049/jimmunol.178.4.2122

178. Delgado M, Gonzalez-Rey E, Ganea D. The neuropeptide vasoactive intestinal peptide generates tolerogenic dendritic cells. J Immunol (2005) 175(11):7311-24. doi:10.4049/jimmunol.175.11.7311

179. ChornyA, Gonzalez-ReyE, Fernandez-Martin A, PozoD, GaneaD, DelgadoM. Vasoactive intestinal peptide induces regulatory dendritic cells with therapeutic effects on autoimmune disorders. Proc Natl Acad Sci U S A (2005) 102(38):13562-7. doi:10.1073/pnas.0504484102

Conflict of Interest Statement: The authors declare that the research was conducted in the absence of any commercial or financial relationships that could be construed as a potential conflict of interest.

Copyright (C) 2018 Hasegawa and Matsumoto. This is an open-access article distributed under the terms of the Creative Commons Attribution License (CC $B Y)$. The use, distribution or reproduction in other forums is permitted, provided the original author(s) and the copyright owner are credited and that the original publication in this journal is cited, in accordance with accepted academic practice. No use, distribution or reproduction is permitted which does not comply with these terms. 